\title{
STAN BADAN \\ NAD ŻYCIEM I SPUŚCIZNĄ RĘKOPIŚMIENNĄ ŚW. JANA Z KĘT
}

W niesłusznie zapomnianej, ale jakże instruktywnej i do dziś wartościowej książeczce o problemach hagiografii w Polsce, o. Jacek Woroniecki przestrzega przed uprawianiem nadmiernego krytycyzmu lub konserwatyzmu w zakresie żywotopisarstwa świętych ${ }^{1}$. Powiada również, że opracowując biografię czy to dla celów beatyfikacyjnych, czy też hagiograficznych ,nie można ponieść dość starań, aby dotrzeć do prawdy historycznej i oczyścić ją z legendy". Chcąc zadość uczynić tym postulatom, a jednocześnie być w zgodzie z dzisiejszymi wymaganiami naukowymi $\mathrm{w}$ zakresie hagiografii, podejmuję próbę metodycznego zreferowania tytułowej problematyki. Uważam, że będzie to z pożytkiem dla dalszych badań nad życiem i kultem św. Jana z Kęt. Takie ujęcie tematyki niniejszej rozprawy wymaga już na wstępie krótkiego wyjaśnienia.

Wokół postaci św. Jana Kantego narosła w ciągu minionych pięciuset lat stosunkowo bogata, lecz bardziej dewocyjno-legendarna niż historyczna literatura. O jej rozmiarach, ilości tytułów i tematyce daje wyobrażenie zestawienie bibliograficzne, zamieszczone po biogramie Jana Kantego pióra M. Rechowicza w I tomie Hagiografii polskiej. Zestawienie to, choć najobszerniejsze w tym temacie, dziś wymaga już wielu uzupełnień i sprostowań. Wymienione tam publikacje i źródła związane merytorycznie $\mathrm{z}$ osobą mistrza $\mathrm{z}$ Kęt możnaby $\mathrm{z}$ grubsza podzielić na dwie grupy tematyczne: pierwsza, biograficzno-źródłowa, ma na celu ukazanie postaci Świętego w konkretnych warunkach historycznych, w jakich przyszło mu żyć, kształtować swój umysł i charakter; druga znacznie obfitsza, obejmuje dzieje jego kultu pośmiertnego i kanoni-

1 Por. J. Woroniecki, Hagiografia, jej przedmiot, trudności i zadania w Polsce, Kraków 1939. 
zacji. Nie przesądzając $\mathrm{w}$ tej chwili wartości tych publikacji - w oparciu o nie bowiem formujemy naszą wiedzę i wyobraźnię o Janie z Kęt trzeba $\mathrm{z}$ naciskiem podkreślić, że wymagają one bardzo wnikliwych i krytycznych studiów. Bogate materiały rękopiśmienne i drukowane począwszy od XV wieku kryją w sobie wiele istotnych szczegółów, które bądź umknęły uwadze dotychczasowych badaczów, bądź też zostały przez nich $z$ takich czy innych powodów fałszywie zinterpretowane. Do tego trzeba dodać postępy nauk historycznych ostatnich lat oraz najnowsze znaleziska archiwalne. Jeżeli więc stosunkowo dobrze jesteśmy poinformowani o rozmiarach i dynamice rozwoju pośmiertnej czci okazywanej św. Janowi $z$ Kęt $w$ naszym kraju i poza jego granicami, to znacznie gorzej przedstawia się historyczny konterfekt naszego Patrona. Kierując się tymi właśnie przesłankami przedstawiam poniżej wyniki moich badań w zakresie tytułowego zagadnienia, świadomie ograniczając się do dwóch tylko, ale za to fundamentalnych rodzajów hagiograficznych źródeł narracyjnych. Przy następnej bowiem sposobności omówię bogate źródła typu dyplomacyjnego oraz inne przekazy historyczne, odnoszące się do osoby św. Jana z Kęt.

WYKAZ SKRÓTÓW ORAZ CZESCIEJ CYTOWANEJ LITERATURY PRZEDMIOTU

BJ

BV

Bossue

HistBJ

$\mathrm{Hp}$

Opatowski, Vita

Opatowski, Żywot

Putanowicz

Rechowicz

Skarga
- Biblioteka Jagiellońska

- Biblioteka Watykańska

- B. BOSSUE, De s. Ioanne Cantio, „Acta Sanctorum” Octobris VIII, Parisiis et Romae 1866, 1042-1106.

- J. ZATHEY, A. LEWICKA-KAMIŃSKA, L. HAJDUKIEWICZ, Historia Biblioteki Jagiellońskiej, Kraków 1966, t. I.

- Hagiografia polska, Warszawa 1971, t. I.

- A. OPATOWSKI, Vita eximii viri Joannis Cantii [...], Cracoviae 1628.

- A. OPATOWSKI, Żywot $i$ cuda wielebnego Jana Kantego [...], Kraków 1632.

- J. A. PUTANOWICZ, Życie, cuda $i$ dzieje kanonizacji św. Jana Kantego [...], Kraków 1780.

- M. RECHOWICZ, Sw. Jan Kanty i Benedykt Hesse w świetle krakowskiej kompilacji teologicznej $z X V$ w., Lublin 1958.

- P. SKARGA, Żywoty świętych Starego i Nowego Zakonu na każdy dzień przez cały rok [...], Kraków 1610. 
Starowolski

Summarium

(1675) albo (1730)

Swastek

Wisłocki

Wisłocki, Katalog

Zawadzki, Lektura

Zawadzki

Żołęaziowski
- S. STAROWOLSKI, Scriptorum Polonicorum 'Eratovís seu centum illustrium Poloniae scriptorum elogia et vitae, Francoforti 1625 .

- „Sacrorum Congregatione Rituum [...]". Positio super dubio an sententia [...]. Summarium super dubio an sententia [...], Romae 1675; j. W., Informatio super dubio an constet [...]. Summarium super dubio an constet [...], Romae 1930. Por. przypis 5 .

- J. SWASTEK, Kolofony św. Jana Kantego w rękopisach Biblioteki Jagiellońskiej w Krakowie, „Archiwa, Biblioteki i Muzea Kościelne", t. 14: 1967, 151-203.

- W. WISŁOCKI, Jan z Kęt Wacięga, ,Sprawozdania z Posiedzeń Akademii Umiejętności w Krakowie za r. 1890, Wydział Historyczno-Filozoficzny", Kraków 1891, 17-23, $29-41,46-48$.

- W. WISEOCKI, Katalog rękopisów Biblioteki Uniwersytetu Jagiellońskiego, Kraków 1877-1881.

- R. ZAWADZKI, Lektura Naukowa św. Jana Kantego, „Analecta Cracoviensia", t. 3:1971, 405-422.

- R. ZAWADZKI, Jagiellońskie rękopisy Jana Kantego w zbiorach rzymskich, „Biuletyn Biblioteki Jagiellońskiej”, t. $26: 1975$.

- [A. ŻOEęDZIOWSKI], Vita s. Ioannis Cantii Poloni. De rebus gestis s. Joannis Cantii [...], Romae 1767.

\section{I. ŹRÓDŁA BIOGRAFICZNO-HISTORYCZNE}

Mimo wielkiego kultu, jakim cieszył się św. Jan Kanty, zwłaszcza w akademickich kręgach, nie znalazł się dotąd nikt, kto by podjął się trudu skreślenia, jeśli nie w pełni hagiograficznego obrazu tej niezwykłej postaci, to przynajmniej ukazania Jana z Kęt w monografii sensu stricto historycznej. Przed osiemdziesięciu z górą laty miał tę ambicję W. Wisłocki, wytrawny mediewista i historyk. Nie wykorzystał on jednak wielkiej szansy, jaką mu dało odnalezienie w zbiorach BJ nie znanych dotąd autografów mistrza z Kęt. W przygotowywanej o nim monografii niepohamowana fantazja autora wzięła niejednokrotnie górę nad rozsądkiem i rzetelnością historyka. Tak właśnie powstały owe ,nowożytne legendy" w biografii Świętego, tyle że na kanwie naukowych rozważań. Jest bowiem rzeczą zastanawiającą, jak wiele z mniej niż hipotetycznych twierdzeń Wisłockiego nabrało $z$ czasem waloru pewnika naukowego 
w zakresie biografii Jana z Kęt. Z niezrozumiałych powodów utrzymują się one do dziś w naszej literaturze hagiograficznej i historycznej. W rezultacie żywot Jana Kantego pozostaje w dalszym ciągu tezą do rozwinięcia, a my zmuszeni jesteśmy zadowalać się nielicznymi opracowaniami typu hagiograficznego, ujmującymi życie i kult pośmiertny mistrza Jana w stopniu bardzo różnym zarówno co do zakresu podawanych informacji, jak też ich wartości merytorycznej.

Całą tę twórczość narracyjną o św. Janie z Kęt, przekazaną przez tradycję pisaną, możemy podzielić na trzy grupy tematyczne: (1) noty bi og r a ficzne - przygodne wzmianki o Kantym, rozsiane w dziełach o najrozmaitszej tematyce: w opracowaniach historycznych i hagiograficznych, w literackich panegirykach prozaicznych i poetyckich, w okolicznościowych mowach, kazaniach itp; (2) bi og r a m y - krótkie, najwyżej parustronicowe kompendia jego życia, cudów i kultu, zamieszczane w kronikarskich opisach historycznych i w zbiorach żywotów świętych; (3) obszerne m o n og r afi e, ujmujące w miarę całościowo problematykę związaną z postacią Swiętego. Spróbujmy omówić merytoryczną zawartość wydzielonych grup i zastanowić się nad wartością źródłową reprezentujących je publikacji. O ile tylko będzie to możliwe zachowamy w naszych rozważaniach porządek chronologiczny referowanego materiału faktograficznego.

\section{NOTY BIOGRAFICZNE}

Krótkie informacje, uwzględniające poza imieniem Świętego zaledwie jego akademicką profesję i datę śmierci, mają w biografii Jana z Kęt znaczenie całkowicie drugorzędne. Są one raczej dowodem skrupulatności historycznej poszczególnych autorów, jak też świadectwem rozwoju kultu Patriarchy krakowskiego, kultu podtrzymywanego zwłaszcza w kręgach uniwersyteckich i mieszczańskich. Trzeba jednakowoż stwierdzić, że te wiadomości historyczne o Janie z Kęt pojawiają się stosunkowo wcześnie, bo już z końcem wieku XV. Jan Długosz własnoręcznie notuje w II tomie Liber beneficiorum ${ }^{2}$, że w kościele akademickim św. Anny w Krakowie spoczywają zwłoki mistrza z Kęt, słynące cudami. Długosz bez wątpienia znał osobiście czcigodnego profesora Uniwersytetu Krakowskiego i dziwić się tylko należy, że pozostawił o nim zaledwie kilka zdań we wspomnianym dziele, nie uczyniwszy zaś o Kantym najmniejszej wzmianki w swojej monumentalnej Historii.

2 Por. J. Długosz, Liber beneficiorum dioecesis Cracoviensis, Cracoviae 1864, t. II, 12. Warto zwrócić uwagę, że Długosz pisał te słowa w 2 lub 3 lata po śmierci Jana Kantego. 
U schyłku XV wieku Hartman Schedel znowu sławi świętość i cuda dokonywane za sprawą Jana Kantego, ale nie notuje żadnych szczegółów biograficznych naszego Patrona ${ }^{3}$.

Dzieło Schedla i w ćwierć wieku po nim Macieja z Miechowa były głównymi źródłami, skąd późniejsi czerpali wiadomości o Janie Kantym. Owe noty biograficzne znajdywane w pracach autorów XVI i XVII stulecia mamy zebrane niemal w komplecie. W zestawieniu ich wyręczyli nas członkowie krakowskiej komisji, przeprowadzającej proces informacyjny w sprawie beatyfikacji mistrza z Kęt. Komisja ta po 40-letniej przerwie ukonstytuowała się po raz wtóry w r. $1667^{4}$. Otóż dla poświadczenia czci i sławy, jaką cieszył się po śmierci Jan Kanty, sporządzono obszerny zestaw autorów i ich dzieł, z przytoczeniem in extenso odnośnych tekstów o Janie $z$ Kęt w porządku chronologicznym ${ }^{5}$. Dlatego też poczet tych cytatów otwiera wspomniany wyżej fragment z Kroniki Schedla, po czym następują wyimki z dzieł takich autorów jak: Miechowita $^{6}$, St. Bistrzycki ${ }^{7}$, Jan z Trzciany ${ }^{8}$, A. M. Sabellicus ${ }^{9}$, M. Bielski ${ }^{10}$, J. Pistorius ${ }^{11}$, St. Sarnicki ${ }^{12}$, by wymienić tylko nazwisko z w. XVI. Autorzy Summariusza cytują również anonimowe opracowania rękopiśmienne $\mathrm{z}$ tego czasu. Jeśli zaś chodzi o autorów $\mathrm{z}$ w. XVII to obok historycznych prac Starowolskiego ${ }^{13}$, Opatowskiego ${ }^{14}$, Warszewickiego ${ }^{15}$,

3 Por. H. Schedel, Liber chronicorum, Nuremberg 1493, f. 268. Treść odnośnego fragmentu Kroniki nabiera szczególnej wymowy, kiedy uświadomimy sobie, że informatorem Schedla o Krakowie miał być sam K. Celtes.

4 Pierwszy etap procesu informacyjnego został rozpoczęty wiosną 1628 roku propria auctoritate bpa M. Szyszkowskiego i po paru miesiącach zakończony. Po kilkunastoletniej przerwie spowodowanej wojnami szwedzkimi wznowiono w r. 1667 przewód beatyfikacyjny Jana Kantego, tym razem już apostolica auctoritate - por. M. Rechowicz, $14 \mathrm{nn}$; Hp I, $544 \mathrm{n}$.

5 Znajdujemy je $\mathrm{w}$ drukowanych aktach procesu kanonizacyjnego opatrzonych zazwyczaj tytułem: Sacra Rituum Congregatione [...] Cracoviensis canonizationis b. Joannis Cantii [...] Positio (vel Informatio) super dubio an itd. Każdy tom tych dokumentów składa się z kilku części, mających swój tytuł i odrębną paginację. Stąd też utrudnione jest ich cytowanie. Interesujące nas zestawienie cytatów o Janie Kantym mieści się $w$ aktach procesu drukowanych w Rzymie w r. 1675 i 1730 , w rozdziale zatytułowanym Summarium i tym skrótem będziemy się w dalszym ciągu posługiwać — por. Summarium (1675), 98-136.

6 Por. niżej przypis 28.

7 Bliżej nieznany autor rękopisu zatytułowanego: Origo ordinis fratrum de poenintentia beatorum martyrum, Cracoviae 1540.

8 Por. Jan z Trzciany (Arundinensis), Vita b. Michaelis, ordinis s. Mariae de Metro(!) de poenitentia beatorum martyrum conventualis s. Marci, Cracoviae scripta anno 1544, Cracoviae $1605,6$.

9 Por. A. M. Sabellicus, Opera omnia, Basileae 1560, 1. X 4, 922.

10 M. Bielski, Kronika wszystkiego świata, Kraków 1551, k. $250 \mathrm{v}$.

11 Por. J. Pistorius, Polonicae historiae corpus, Basileae 1582, t. II, 231 sq. Jest to przedruk Kroniki Miechowity.

12 Por. St. Sarnicki, Descriptio veteris et novae Poloniae, Varsaviae 1585, f. $\mathrm{D} 1 \mathrm{v}$.

13-14 Por. niżej s. $16,19 \mathrm{n}$.

15 Por. [K. Warszewicki], Reges, sancti, bellatores, scriptores Poloni, Romae 1601, 13. 
Nakielskiego ${ }^{16}$, Spondanusa ${ }^{17}$, Bzowskiego ${ }^{18}$, Pruszcza ${ }^{19}$ i paru innych pojawiają się fragmenty kazań (Zakrzewski, Morawski) i panegiryków (Viteliusz). Czytając odnośne fragmenty tych tekstów stwierdzamy, że zawierają one najczęściej jedynie datę śmierci Jana Kantego, przy czym jest ona różna u różnych autorów w zależności od tego, skąd dany pisarz czerpał potrzebne wiadomości ${ }^{20}$. Jeśli więc za Miechowitą przytacza Sabellicus, Pistorius czy Bzowski rok śmierci Jana Kantego - 1473, to u Jana z Trzciany i Warszewickiego mamy 1471, a Bielski podaje wiadomość o „Janie z Kantów” pod rokiem 1475. Oczywiście listę cytatów o Janie z Kęt, zapoczątkowaną przez profesorów krakowskich w XVII wieku, moglibyśmy dzisiaj uzupełnić tekstami nie tylko $\mathrm{z}$ czasów nam bliższych, ale również rozszerzyć tamto zestawienie o pozycje, które umknęły uwadze jego kompilatorów, lub pozostały w nie znanych im rękopisach. Czy tego rodzaju suplement będzie rzeczywiście potrzebny, okaże się przy opracowywaniu dziejów kultu św. Jana z Kęt.

Osobną uwagę należy poświęcić tekstom panegiryczno-poetyckim, gdzie również znajdujemy elementy biograficzne naszego Patrona. Utwory te to przeważnie okolicznościowe kazania lub wiersze. Jest ich ogromna ilość zarówno z w. XVII jak i XVIII ${ }^{21}$. Barokowość stylu przytłacza w nich wielosłowiem konkretność danych historycznych. Nie mniej cała ta obfita twórczość poetycko-kaznodziejska jest nie tylko przykładem pewnej maniery retorycznej i literackiej w ogóle, ale również ma swój walor hagiograficzny, a nawet historyczny, tyle że rozpatrywany $\mathrm{w}$ innym kontekście problemowym ${ }^{22}$. Twórczość kaznodziejska ukazuje nam zasięg i rozmiary kultu Jana Kantego w Polsce od początku w. XVII. Obejmuje ona najprzeróżniejsze środowiska lokalne i społeczne. Obok księży profesorów z Akademii Krakowskiej i innych szkół (Tarnów, Poznań, Warszawa, Lwów, Zamość i wiele innych) głoszą na jego cześć mowy pochwalne jezuici (!). Podczas październikowych uroczystości ku czci Jana Kantego wysławiają krakowskiego profesora pospołu domini-

16 S. Nakielski w swym ogromnym dziele (Miechovia sive promptuarium antiquitatum monasterii Miechoviensis, Cracoviae 1634) zamieścił tylko dwie krótkie wzmianki o Janie Kantym (s. 364 i 533), odsyłając czytelnika do monografii Opatowskiego. $\mathrm{Z}$ pewnością poświęciłby Kantemu więcej miejsca, gdyby dotarł do wiadomości o jego pobycie w Miechowie w latach 1422-1428, która wszakże wypłynęła znacznie później z rękopisów mistrza z Kęt.

17 Por. de Sponde (Spondanus) H., Annalium ecclesiasticorum [...] Caesaris Baronii continuatio, Lugduni 1678. T. II, 142.

18 Por. A. Bzowski, Annalium ecclesiasticorum [...] tomus VIII. Coloniae Agrippinae 1627,38 .

19 Por. H. Pruszcz, Klejnoty stołecznego miasta Krakowa, Kraków 1861, 31.

20 Pouczające zestawienie tych informacji daje B. Bossue, 1050.

21 Wykaz tych druków zawarty w Bibliografii polskiej K. Estreichera i powtórzony w Hp (I, 552-555) stanowi mniej więcej połowę znanych mi tytułów o tej tematyce.

22 Por. J. Pelc, Obraz - Słowo - Znak. Studium o emblamatach $w$ literaturze staropolskiej, Wrocław 1973, 230, 243. 
kanie i franciszkanie, karmelici i bernardyni, by wymienić tylko najważniejsze zakony podtrzymujące jego kult. Te i wiele innych przejawów kultu św. Jana Kantego w ciągu minionych stuleci to już osobny temat. Zwracam jedynie uwagę na tę formę religijności oraz na fakt, że wiąże się z nią szereg innych zagadnień.

Inny nieco charakter i zasięg czasowy ma poetycka tradycja dotycząca Jana Kantego. Pierwsze ślady tej twórczości datują się na koniec wieku XV. W nieokreślonych bliżej okolicznościach powstały wówczas dwa epitafia. Pierwsze, zaczynające się od słów: Inter gymnasii clarissima Cracoviensis, miał umieścić na grobie właśnie zmarłego mistrza Jana Mikołaj Tauchen z Nysy ${ }^{23}$. Epitafium to znane jest $z$ zaginionego rękopisu zawierające bliżej nieokreślony komentarz Alberta W. do Etyki Arystotelesa. Kodeks ${ }^{24}$ musiał być znany profesorom krakowskim jeszcze w w. XVII, skoro odpis wiersza znajdujemy w aktach kanonizacyjnych z r. 1675. Epitafium Tauchena ważne jest o tyle, że z tych 18 wierszy dowiadujemy się po raz pierwszy m. in. o tym, że Kanty był Ślązakiem, i że pielgrzymował do Ziemi Świętej. Więcej interesujących nas wiadomości biograficznych zawiera anonimowa Vita beati Joannis Cantii ${ }^{25}$. Co najmniej od czasów H. Zeissberga ${ }^{26}$ szukano wskazówki, która by naprowadziła na ślad autora tego heksametrycznego poematu. Kierując się wielce prawdopodobną hipotezą niemieckiego historyka można by przypuszczać, że ułożył go Ruttgerus Siccamber, autor epigramów o św. Annie. Poemat ten znany był już Maciejowi z Miechowa. Twórca owego Żywotu Jana $z$ Kęt już nie wspomina o śląskim pochodzeniu mistrza, ale mówi o rodzinnych Kętach, o pobieranych naukach, o czterokrotnej pielgrzymce do Rzymu i do Jerozolimy, o chwalebnych cno-

23 Prawdopodobnie Tauchen istotnie parał się tego rodzaju twórczością, bowiem w rękopisie BJ 689 (f. 122v) znajdujemy inne jego 10 -wierszowe epitafium na cześć kasztelana krakowskiego Jana z Tenczyna. Epitafium o Janie Kantym przedrukował z Summariusza $(1675,134 \mathrm{n}) \mathrm{W}$. Wisłocki, Incunabula typographica Bibliothecae Universitatis Cracoviensis, Cracoviae 1900, 130.

24 Kodeks ten należał kiedyś do Bernarda Mikosza z Nysy, ale nie ma żadnej pewności czy został wysłany do Rzymu w czasie procesu kanonizacyjnego Jana z Kęt - por. W. Wisłocki, Incunabula, jw.; HistBJ, 120.

25 Poemat, zaczynający się od słów Carmine ne sileas został opublikowany (wraz z epigramami na cześć św. Anny) jako dodatek do Modus epistolandi Jana Sacranusa z Oświęcimia (Cracoviae 1520). Edycja ta wyszła staraniem Stanisława z Łowicza, seniora bursy Jerusalem. W niespełna 100 lat później nowe wydanie tych wierszy sporządził P. Świętkowicz (Kraków 1608).

26 H. Zeissberg (Dziejopisarstwo polskie wieków średnich, Warszawa 1877, t. I, 249) powiada, że w dziele Jana Trithemiusa ze Spanheim (De laudibus sanctissimae matris Annae tractatus, Lipsiae b.r.) zostało pomieszczone to samo Carmen saphicum in laudem s. Annae, jakie znajdujemy $\mathrm{W}$ rękopisie Ossolineum $653 \mathrm{i}$ po Vita b. Joannis Cantii w edycji z r. 1520 . Otóż Trithemius przypisuje to Carmen właśnie Rutgerowi Siccambrowi, bliżej nie znanemu poecie. Już po oddaniu tej rozprawy do druku dotarła do mnie monografia K. Arnolda o Trithemiuszu, rozstrzygająca negatywnie wysuniętą tutaj kwestię - por. K. Arnold, Johannes Trithemius (1462-1516), Würzburg 1971, $104 \mathrm{nn}$. 
tach i cudach Świętego. Na jakich źródłach opierał się tutaj autor, trudno powiedzieć. Barokowa poezja XVII i XVIII stulecia z lubością podjęła wdzięczny temat legendarnych dziejów Janowego żywota. Pojawia się mnóstwo różnego gatunku ód i epigramów drukowanych głównie z okazji promocji uniwersyteckich. Dla biografii mistrza z Kęt nie posiadają one żadnej wartości źródłowej ${ }^{27}$.

\section{BIOGRAMY}

Pierwszą obszerniejszą wiadomość o Janie Kantym znajdujemy w Kronice Polaków Macieja z Miechowa ${ }^{28}$. Autor nie podaje jednak żadnych konkretnych danych biograficznych Świętego, prócz daty śmierci w r. 1473. Z emfazą natomiast wysławia cnoty i dokonane przez krakowskiego profesora za życia i po śmierci liczne cudowne uzdrowienia, wspomina jego pielgrzymki, cytuje epigram rzekomo wypisany przez Kantego na ścianie swojej izdebki, wreszcie przytacza cztery początkowe wiersze anonimowego epitafium „Carmine ne sileas”. Nie są nam znane źródła tego opisu. Podane wszakże w Kronice wiadomości o Janie Kantym zostały w całości przejęte przez późniejszych historyków i hagiografów. W pracach tych ostatnich odnośny fragment $z$ Miechowity był najstarszym zalążkiem legendy narastającej wokół postaci krakowskiego mistrza.

Wbrew dotychczasowej tradycji przyjmującej, że P. Skarga był pierwszym autorem właściwego biogramu Jana z Kęt, okazuje się, iż w tej pracy wyprzedził go o lat parę inny konfrater Skargi. Był nim Fryderyk Schembek, zaciekły przeciwnik krakowskich profesorów, ale przy tym wszystkim szczerze przejęty kultem (nie tylko) mistrza $z$ Kęt. Schembek napisał bowiem jakieś żywoty świętych polskich, a wśród nich nie dostrzeżony dotąd życiorys Jana Kantego. Biogram ten jest o tyle ważny i interesujący, że warto mu poświęcić więcej miejsca.

W „Przydatku” do VII wydania Żywotów P. Skargi 29 znajdujemy obok biogramu św. Stanisława Kostki i królewicza Kazimierza również życiorys Jana Kantego. W redagowaniu tego ostatniego biogramu Skarga nie był samodzielny. Tekst swój rozszerzył o przekład wspomnianego wyżej fragmentu z Kroniki Miechowity, dodając opis kilku cudów późniejszych i passus o rewerendzie mistrza Jana. Te dwa ostatnie elementy biograficzne poprzedzone zostały wyróżnionym graficznie akapitem, z którego dowiadujemy się, że Skarga otrzymał pewne materiały

27 Jako ciekawostkę wspomnę jeszcze apokryficzny Sacrofac bł. Michałowi [Giedroyciowi] od bł. Jana Kantego uczyniony. To 10-wierszowe epitafium ogłosił H. Pruszcz, Forteca monarchów [...], Kraków 1737, 183.

28 Por. Maciej z Miechowa, Chronica Polonorum, Cracoviae 1519, $337 \mathrm{n}$.

29 Por. P. Skarga, Żywoty świętych Starego $i$ Nowego zakonu, Kraków 1610, $1162-1166$. 
biograficznego o Janie z Kęt od Fr. Schembeka. Miał on bowiem wykorzystać archiwalia przechowywane u św. Anny i porobić z nich notatki, udostępnione następnie Skardze. Kiedy w r. 1628 wszczęto przewód informacyjny $\mathrm{w}$ sprawie beatyfikacji Jana $\mathrm{z}$ Kęt, jednym $\mathrm{z}$ pierwszych, który złożył odpowiednie zeznanie przed komisarzami wyznaczonymi przez bpa M. Szyszkowskiego, był właśnie Fr. Schembek. Przedziwnym zrządzeniem Opatrzności zachował się protokół z tego posiedzenia w dniu 27 kwietnia i dziś możemy poznać treść zeznań Schembeka wziąwszy do ręki sławny i znany dosłownie od pięciuset lat (naturalnie z późniejszymi dodatkami) rękopis BJ 105 (k. 28-33) ${ }^{30}$. Schembek z wielkim pietyzmem wyraża się o byłym profesorze Akademii Krakowskiej, potwierdzając nieprzerwaną ciągłość kultu otaczającego Sługę Bożego od chwili jego zgonu w r. 1473. Dla nas jednak najciekawszym jest passus zamieszczony na $\mathrm{k}$. $31^{\mathrm{r}}$ :

Cum quoque r.p. Heribertus Rosvejdus, societatis nostrae, diligentia sua indaganda veteribus sanctorum historiis insignis postulasset sibi in Belgium mitti vitas sanctorum regni istius [sc. Poloniae] quae hactenus numquam lucem viderant [...] i p se met ego desiderio suo misi eidem r.p. Rosvejdo vitam manuscriptam eiusdem viri Dei [sc. Ioannis de Kęty] una cum ceteris vitis manuscriptis beatorum provinciae istius.

Sięgnijmy teraz po VIII tom Acta Sanctorum (Octobris), gdzie pomieszczony został obszerny artykuł o św. Janie z Kęt, opracowany przez Beniamina Bossue. Otóż na początku rozdziału 8 (s. 1044) czytamy następującą uwagę autora:

Habemus inter manuscripta hagiographica praedecessorum nostrorum registrum manu ipsius Bollandi exaratum, in quo ad diem 24 decembris haec notantur: B. Joannis Cantii vitam habemus ex Michovio(!) desumptam, quae incipit: Beatus Joannes cantius, Polonus, sacrae theologiae doctor et publicus celebris Academiae Cracoviensis professor etc. Sunt 6 folia.

Jeśli zestawimy powyższe trzy informacje, łatwo dochodzimy do wniosku, że autorem tych sześciu kart z życiorysem Jana Kantego, jakie miał przed sobą Bollandus jest właśnie Fr. Schembek, jezuita krakowski, albowiem odnośny fragment o Kantym u Miechowity obejmuje niecałe dwie strony. To właśnie Schembek w r. 1603 przesłał H. Rosweyowi, faktycznemu inicjatorowi monumentalnej edycji Acta Sanctorum, żywot Jana Kantego, wspomniany w krakowskim protokole z r. 1628. Opo-

30 Rks BJ 105 składa się z 38 kart papierowych, zawierających zeznania dotyczące cudów i kultu Jana Kantego. Spisywanie ich zapoczątkował Maciej z Kościana w r. 1475. Tę najstarszą część rękopisu ogłosił W. Kętrzyński w Pomnikach Dziejowych Polski (t. VI, 481-533). Dalszy ciąg tego katalogu cudów mamy w rękopisie BJ 141 (f. $31-64$ ). 
wiedziana historia nie byłaby sama w sobie tak ważna, gdyby nie fakt, że właśnie w tym biogramie Kantego występuje po raz pierwszy i jak dotąd jedyny w całej literaturze poświęconej Swiętemu pełne nazwisko jego ojca - Stanislaus Vacenga. B. Bossue przedrukował bowiem (s. 1049) początkowy fragment $\mathrm{z}$ tekstu Schembeka, mówiący o miejscu urodzin Kantego i jego rodzicach. Niestety nie umiem odpowiedzieć na rodzące się w tym miejscu pytanie, skąd Schembek zaczerpnął informacje o takiej właśnie postaci nazwiska. Sam powołuje się na archiwalia złożone w kolegiacie św. Anny, a te przecież z czasem przekazano do Biblioteki Jagiellońskiej. Wypada więc tylko stwierdzić, że przytoczona przez Schembeka nazwa osobowa Vacenga jest poprawna pod względem morfologicznym, to też nie można wykluczyć jej użycia w funkcji onomastycznej ${ }^{31}$.

Wróćmy jednak do dalszych biogramów Jana Kantego, napisanych w wieku XVII. Jedyny nowy szczegół wniesiony przez nie do opisu jego życia dotyczy rękopisów odnalezionych w zbiorach Collegium Większego. Podaje bowiem Starowolski, że Jan Kanty miał być autorem trzytomowego Komentarza do św. Mateusza i zbioru kazań ${ }^{32}$. Poza tą wiadomością Starowolski czerpał inne z życiorysów napisanych przez Skargę i Macieja z Miechowa. Być może sięgnął również do ksiąg uniwersyteckich.

Kolejni żywotopisarze Jana z Kęt rozmaicie dobierali źródła do swoich opracowań. I tak A. Bzowski (1627) ${ }^{33}$ prawie bez zmian powtórzył odpowiedni fragment z Kroniki Macieja z Miechowa, pomijając zupełnie biogramy napisane przez Skargę i Starowolskiego. Z początkiem wieku XVIII nacjonalista śląski Marcin Hancke (1707), powołując się na Skargę, Starowolskiego i Opatowskiego powtórzył znane szczegóły biograficzne Świętego, ale za Joachimem Curaeusem ${ }^{35}$ odgrzebał dawno zapomnianą tezę o śląskim pochodzeniu Jana Kantego. Mnożące się w XVIII i XIX wieku wielotomowe żywoty świętych traktowały o św. Janie Kantym $\mathrm{z}$ rozmaitą rzetelnością historyczną. Jeszcze $\mathrm{w}$ roku jego

31 Por. S. D. Kozierowski, Nazwiska, przezwiska, przydomki, imiona polskie niektórych typów słowotwórczych, Poznań 1938, 69 n. Autor daje przykłady imion ze spółgłoską -g- o przyrostku -ąg/ęga, np. Mrowięga, Mitręga, Maciąg, Macięga, Wałęga, Wardęga itp. Przy nazwisku Wacięga Kozierowski nie podaje źródła tego zapisu, a tylko stwierdza, że odnosi się ono do św. Jana Kantego. Por. niżej s. $25 \mathrm{n}$.

32 Por. S. Starowolski, 33-35; Summarium (1675), 115-118.

33 Por. przypis 18.

34 Por. M. Hancke, De Silesiis indigenis eruditis [...], Lipsiae 1707, 153-155.

35 Por. J. Curaeus, Gentis Silesiae annales, Wittembergae 1571; B. Bossue, 1047-1049. Problem ten jest bezprzedmiotowy, choć jego źródło jest historycznie uzasadnione. Chodziło o to, że księstwo oświęcimsko-zatorskie od r. 1179-1456 w sensie politycznym nie należało do Polski, jednakże jako dekanat zawsze podlegało iurysdykcji arcybiskupa krakowskiego, gdyż wiadomo, że w średniowieczu granice państwowe nie pokrywały się z granicami diecezji - por. J. Szymański, Struktura organizacyjna biskupstw polskich $w$ wiekach średnich, „Znak" 137/8 (1965), s. $1408 \mathrm{nn}$. 
kanonizacji (1767) F. Jaroszewicz, autor bardzo poczytnego zbioru żywotów świętych polskich, bez skrupułów przerabia jedynie tekst Skargi na podstawie któregoś z wydań sobie współczesnych ${ }^{36}$. Z chwilą opublikowania przez A. Żołędziowskiego (1767) ${ }^{37}$ wersji łacińskiej i włoskiej opracowanego przez siebie żywotu świeżo kanonizowanego mistrza z Kęt, przybyła następnym hagiografom kolejna szablonowa biografia. Do tego doszło jeszcze Compendium Vitae ${ }^{38}$, wydane parę razy bezimiennie, jednakże przy redagowaniu i tego opracowania życiorysu Jana Kantego nie można wykluczyć udziału A. Żołędziowskiego. Na tym ,kanonizowanym" życiorysie opiera się inne anonimowe Opisanie życia (1768) ${ }^{39}$. Edycja tej ostatniej książeczki przeznaczona została raczej dla rozkrzewienia kultu kanonizowanego profesora Akademii Krakowskiej, toteż zawiera przede wszystkim modlitwy i pieśni o nim, a sam życiorys Świętego jest tu tylko dodatkiem bardziej moralizatorskim niż historycznym. Prymitywność innych biogramów św. Jana Kantego opracowanych w tym czasie uwalnia nas od obowiązku zajmowania się nimi w tym miejscu.

Począwszy od wieku XIX zależność biogramów Jana Kantego od wykorzystywanych przez nich źródeł staje się ze zrozumiałych względów bardziej złożona i wielopłaszczyznowa. W ogólnych zarysach biogramy Jana Kantego od tej chwili łączy wspólna cecha; poza drobnymi korekturami trzeciorzędnych szczegółów rzeczowych nie wprowadzają one nic nowego do ugruntowanej przez Miechowitę, Skargę i Opatowskiego wersji biografii św. Jana z Kęt, nadając jej najczęściej kształt literackiej opowieści, w której trudno rozróżnić legendę od wydarzeń historycznych. Ich to również miał zapewne na myśli o. Jacek Woroniecki, kiedy we wspomnianej książeczce piętnował tego rodzaju dyletantów w hagiografii.

Inne kryteria należy zastosować przy ocenie dwóch opracowań żywotu mistrza z Kęt; chodzi o wymienioną już rozprawę W. Wisłockiego oraz o najnowszy biogram św. Jana Kantego, zamieszczony przez ks. M. Rechowicza w I tomie Hp (s. 536-548). Górują one nad pozostałymi dzięki temu, że ich autorzy w znacznej mierze posłużyli się w swej pracy archiwaliami, a głównie autografami mistrza z Kęt. Pracę Wisłockiego omówimy $\mathrm{w}$ rozdziale następnym $\mathrm{z}$ tego względu, że, choć zachowało

36 Por. F. Jaroszewicz, Matka Swiętych Polska, Kraków 1767, 496-499.

37 Por. niżej s. 21.

38 Por. Compendium vitae, virtutum et miraculorum nec non actorum in causa canonisationis b. Joannis Cantii [...], Romae 1767; J. A. Mariotti, Acta canonisationis sanctorum Joannis Cantii, Josephi Calasantii [...] collecta ac notationibus illustrata, Romae 1769, 113-120; Begriff des Lebens des hl. J. Cantius, Insbruk 1771.

39 Por. Opisanie życia, światobliwości, nauk $i$ niektórych cudów św. Jana Kantego [...] $z$ przydatkiem septenny albo siedmioczwartkowego nabożeństwa do tegoż świętego, Kraków 1768. 
się po niej tylko streszczenie, pomyślana była przez autora jako obszerna biografia Jana Kantego. Natomiast biogram opracowany przez M. Rechowicza wymaga kilku słów omówienia.

Największym walorem tej pracy jest umiejętne połączenie materiału historycznego i hagiograficznego, dzięki czemu sylwetka Swiętego w swojej całej cudowności nabiera realnych, ludzkich wymiarów. Autor zebrał i usystematyzował dotychczasowe wyniki badań nad życiem i dziejami kultu św. Jana Kantego uzupełniwszy je własnymi studiami, zwłaszcza w zakresie spuścizny rękopiśmiennej mistrza z Kęt. Uwagi ks. Rechowicza właśnie na ten ostatni temat są najbardziej oryginalną częścią biogramu. Jeśliby mu można coś zarzucić, to chyba tylko zbyt słabe podkreślenie hipotetyczności niektórych informacji, szczególnie gdy idzie o różne fakty z życia Jana Kantego. Przecież imiona jego rodziców znane są dopiero $z$ biogramów siedemnastowiecznych i nie wiemy zupełnie, jakie jest ich źródło historyczne. Przyjęcie za prawdopodobne, podawane przez Wisłockiego przypuszczenia na temat miejsca urodzin Jana Kantego (Malec, Marta) skłania, zwłaszcza czytelnika nieobeznanego dokładnie w przedmiocie sprawy, do przyjęcie tych pomysłów za fakty historycznie dowiedzione. Tymczasem argumentacja Wisłockiego na temat Malca i nazwiska Wacięga jest nie tylko nieprzekonująca, ale przede wszystkim bałamutna i miejscami wręcz błędna, nawet jeśli na usprawiedliwienie autora uwzględnimy ówczesny stan wiedzy historycznej i filologicznej. Również bez uzasadnienia podał ks. Rechowicz dziewięcioletni okres pobytu Jana Kantego w Miechowie (1421-1429), choć znowu jest to supozycja Wisłockiego, wymagająca dziś korekty na podstawie tych samych materiałów, jakimi ten ostatni dysponował. Powtarzanie za Z. Siemiątkowską domysłów o zainteresowaniach muzycznych św. Jana Kantego jest o tyle dezinformujące, że rks BJ 2464 nie jest autografem Świętego, nigdy nie należał do jego biblioteki i najprawdopdobniej nie miał go on w ogóle w rękach. W przeciwieństwie do tych znaków zapytania, jakie można by postawić przy wielu datach i zdarzeniach z życia Jana Kantego, należało z większą ostrością podkreślić te fakty, których wiarygodność zasadza się bądź na zapiskach znajdowanych w jego rękopisach, bądź na innych współczesnych źródłach historycznych. Jest bowiem rzeczą zastanawiającą, jak mało znajdujemy tych świadectw w długim i bogatym życiu mistrza z Kęt. Poza datą urodzin (24 XII 1390), karierą uniwersytecką i działalnością pisarską wszystkie inne szczegóły z Jego życia są domysłem bardziej lub mniej prawdopodobnym, ale tylko domysłem. Piszę te uwagi dlatego, aby wskazać jak wiele jeszcze jest do odkrycia i udowodnienia w biografii naszego św. Patrona, zaś punktem wyjścia tych poszukiwań musi być odtąd artykuł ks. Rechowicza o św. Janie Kantym, pomieszczony w I tomie Hagiografii polskiej. 


\section{MONOGRAFICZNE OPRACOWANIA ŻYWOTU ŚW. JANA Z KET}

Jest faktem zastanawiającym, że w XV wieku nie znajdujemy poza Długoszem innego autora, zajmującego się pisaniem żywotów świętych Pańskich. Chodzi oczywiście głównie o polskich świętych, którymi tak bardzo promieniał wiek XV - felix saeculum. Zwróćmy uwagę na to, że cuda tylko dwóch osób z tej epoki, zmarłych w opinii świętości, zaczęto spisywać niemal nazajutrz po ich śmierci. Tak bowiem było z królową Jadwigą i Janem z Kęt. Kult tych osób w XV wieku, jego dynamizm i spontaniczność nie zaskakują nas. W tej sytuacji dziwi jedynie to, że nikt wówczas nie podjął się nakreślenia życiorysu którejś z tych niezwykłych indywidualności, choćby tylko dla celów dewocyjnych. K. Górski przypuszcza ${ }^{40}$, że ten stan rzeczy należy przypisać bardzo silnemu oddziaływaniu tradycji ustnej, przewyższającej, w odczuciu współczesnych, wartość słowa pisanego tam, gdzie chodzi o ukazanie nadprzyrodzonych cnót osób otaczanych kultem. Myślę, iż właśnie ta „,cudowność" wypełniła wyobraźnię ludzi tamtych czasów do tego stopnia, że w niej właśnie dopatrywano się wystarczającego historycznie dowodu istnienia owych postaci. Trzeba pamiętać, że jeszcze wówczas obowiązywał typ świętego - admirandus non imitandus. Powolne zanikanie z czasem przejawów kultu zewnętrznego, zwłaszcza w stosunku do osoby zmarłej niezbyt dawno, tym skuteczniej odsuwało w czasie możliwość podjęcia o niej hagiograficznego tematu przez kogokolwiek.

Jeśli idzie o Jana Kantego to powszechne zainteresowanie jego osoba i znaczne ożywienie kultu wzrosło szczególnie w trzech okresach: ostatniej ćwierci w. XV (samorzutny kult Świętego po jego śmierci w r. 1473), w wieku XVII, podczas rozpoczęcia procesu beatyfikacyjnego (1628) i jego zakończenia (1680), wreszcie w połowie wieku XVIII, gdy proces kanonizacyjny miał się ku szczęśliwemu końcowi (1767). Schyłek wieku XV nie przyniósł, jak już to stwierdziliśmy, ,rozumowej” biografii Jana Kantego. Dopiero inicjatywa bpa M. Szyszkowskiego spowodowała, że przygotowania do otwarcia przewodu beatyfikacyjnego zostały poprzedzone zebraniem odpowiedniego materiału historycznego. Zadanie to powierzono w pierwszym rzędzie Adamowi Opatowskiemu, profesorowi teologii w Akademii Krakowskiej, proboszczowi u św. Anny, a więc człowiekowi, który miał najłatwiejszy dostęp no archiwaliów kolegiaty akasemickiej ${ }^{41}$. Tak zrodziła się pierwsza pełna monografia o życiu i cudach Jana z Kęt. Opatowski napisał dwa jego życiorysy: pierwszy krótszy Vita - ukazał się po łacinie w r. 1628, drugi - trzykrotnie obszerniejszy Żywot - po polsku, w cztery lata później (1632). Rozszerzenie

40 Por. K. Górski, Od religijności do mistyki, Lublin 1962, 35.

41 Por. F. Bracha, Adam Opatowski, „Nasza Przeszłość” III. 121-144. 
wersji polskiej spowodował nie przez wprowadzenie nowych danych biograficznych, ale dodając opis stu kilkudziesięciu cudów dokonanych za sprawą Kantego od chwili śmierci do czasów bliskich Opatowskiemu ${ }^{42}$. Widać z tego, że autor postawił sobie za cel wykazanie heroiczności cnót teologicznych i kardynalnych oraz sposobu ich rozwijania i pogłębiania za życia, co miało budzić podziw u współczesnych, a co potomni podtrzymali, darząc wielką czcią relikwie Sługi Bożego. W obu opracowaniach zastosował autor dwa rodzaje opisu biograficznego. Dawny, uprawiany przez żywotopisarzy średniowiecznych, dla których święty otoczony nimbem doskonałości moralnej i umysłowej, nimbem „cudowności", miał być przede wszystkim admirandus, uzupełnił panującą w ówcznej hagiografii formą opisu życia świętych, akcentującą wartość ich naśladowania, dzięki czemu święty staje się imitandus. Przyjęte przez Opatowskiego zasady kompozycji formalnej dzieła spowodowały ograniczenie do minimum wiadomości historycznych odnoszących się do życia Jana Kantego, do środowiska rodzinnego i uniwersyteckiego, do warunków życia wielkomiejskiego. Nieliczne informacje na ten temat giną w powodzi zbytecznych słów. Taka jednak maniera literacka obowiązywała podówczas. Opatowski skrupulatnie wykorzystał wzmianki biograficzne o Kantym znalezione $\mathrm{u}$ innych autorów, zwłaszcza u Miechowity, Starowolskiego i Skargi (tego ostatniego przez niechęć do jezuitów nie wymienia). W przeciwieństwie do swych poprzedników dokładniej przeglądnął księgi uniwersyteckie i autografy patriarchy krakowskiego. Na tej podstawie mógł w wersji polskiej skorygować uprzednio przyjętą datę urodzin Jana Kantego (1397) i przesunąć ją o siedem lat wstecz (24 VI 1390), zgodnie $\mathrm{z}$ treścią kolofonu na końcu trzeciej części Komentarza do św. Mateusza ${ }^{43}$. Jednakże element cudowności zmajoryzował (zwłaszcza w Żywocie) treść biograficzno-historyczną, a nawet moralizatorską.

Kiedy w drugiej połowie w. XVII wznowiono proces beatyfikacyjny Jana Kantego, tekst Vita został wciągnięty do akt procesowych ${ }^{44}$. Ta właśnie wersja dzieła Opatowskiego dzięki komunikatywnemu językowi

42 Oryginał łaciński tych cudów w rękopisie BJ 105 i 141, - por. przypis 30.

43 Dziś rkps Vat. Lat. 14646 , - por. J. Swastek, 202.

$44 \mathrm{~W}$ tymże 1667 roku (por. przypis 4) ogłoszono drukiem całą dokumentację biograficzną Jana z Kęt. I tak dzieło Opatowskiego streszczono po polsku ná dwóch kartach, opatrzonych tytułem: Krótkie zebranie życia sługi Bożego wielebnego Jana Kantego [...] z opisania szerokiego żywotu jego przez [...] A. Opatowiusza wydanego. W podobnej formie opublikowano: Mattias de Miechów, S. Starovolscius, A. Bzovius, Vita servi Dei Joannis Cantii; Żywot bł. Jana Kantego [...] od wielebnego Piotra Skargi [...] napisany; Excerpta ex historicis variis de servo Dei Joanne Cantio (b.m.r.). Druk ostatni wyszedł w dwóch wersjach: jednofoliowe opracowanie zawiera cytaty z Schedla, Sabellicusa, Wapowskiego, synodu piotrkowskiego (1628), W. Morawskiego i Długosza; wersja dłuższa (12 kart) poza cytatami z wymienionych autorów posiada jeszcze inne, jak: Miechowity, Bzowskiego, Starowolskiego, Skargi, Opatowskiego. 
i niewielkim rozmiarom zadecydowała, że zarówno $\mathrm{w}$ bulli beatyfikacyjnej (1680), jak i kanonizacyjnej (1767) przyjęto datę urodzin św. Jana $\mathrm{z}$ Kęt - 24 VI 1397. Vita eximii viri Ioannis Cantii pozostawała co najmniej przez dwa stulecia głównym i uznanym źródłem informacyjnym w zakresie biografii mistrza z Kęt. Ale około połowy w. XVII ukazała się jeszcze jedna biografia. Był to anonimowy druk pochodzący z królewskiej oficyny Eukasza Kupisza (1648) - Vita servi Dei Ioannis Cantii. Autor tego opracowania streścił pokrótce wywody swoich poprzedników i nie tym oczywiścié zyskał sobie takie uznanie, że wznowiono jego kompilację w r. 1712, a późniejsi biografowie Jana Kantego nieraz się odwoływali do informacji zawartych w tej książeczce. Głównym powodem tego uznania był przekonywający wywód na temat daty urodzin Jana z Kęt. Zdaniem autora rok 1397 jest dlatego trafny, że Jan Kanty zapisał się na uniwersytet w wieku młodzieńczym czyli mając, jak jego rówieśnicy, lat około 16, tzn. w r. 1413, jak poświadcza metryka uniwersytecka. Ta argumentacja tak przypadła do gustu historykom, że puszczono w niepamięć Żywot Opatowskiego, a z czasem zlekceważono nawet autobiograficzne zapiski $\mathrm{w}$ odnalezionych rękopisach mistrza $\mathrm{z}$ Kęt. Nic już nie zdołało podważyć raz przyjętej i w końcu „,kanonizowanej” datacji.

W połowie XVIII stulecia proces kanonizacyjny Jana Kantego miał się szczęśliwie ku końcowi, toteż znacznie wzrosło zainteresowanie życiem nowego świętego. Wreszcie w r. 1767, w roku kanonizacji sześciu świętych przez Klemensa XIII (Jan Kanty, Józef Kalasamty, Józef z Cupertino, Hieronim Emiliani, Serafin z Asculo, Joanna Franciszka Fremio de Chantal), ukazują się łacińskie i włoskie opracowania ich żywotów. Biografia św. Jana Kantego ukazała się anonimowo w Rzymie, w obu wersjach językowych jednocześnie. Między oboma tekstami istnieją pewne różnice, dlatego nie można powiedzieć, że jedna jest dosłownym przekładem drugiej. Przyjmuje się, że autorem tej dwujęzycznej biografii św. Jana z Kęt był Antoni Żołędziowski, ostatni (od r. 1752) z ramienia Uniwersytetu Krakowskiego postulator kanonizacji mistrza Jana ${ }^{45}$. Nie wydaje się możliwe, aby ktoś innym w tym czasie był bardziej kompetentny od Żołędziowskiego w podjęciu tego tematu. Naturalnie Żołędziowski pisał biografię Kantego wyłącznie w oparciu o materiały za-

45 A. Żołędziowski zmarł jako rektor UJ 24 VIII 1783. Podczas egzekwii w roku następnym (8 VI) wygłosił piękne przemówienie Jan Śniadecki, podnosząc w nim inteligencję Żołądziowskiego, jego gorliwość i obowiązkowość, zrozumienie dla reform Kołłątajowskich, wreszcie zasługi w jego staraniach o kanonizację św. Jana z Kęt - por. L. Kamykowski, Nieznana mowa Jana Sniadeckiego, „Prace naukowe oddziału warszawskiego Komisji do badania dziejów wychowania i szkolnictwa w Polsce", Warszawa 1927, 44-48. 
twierdzone w procesie kanonizacyjnym. Dlatego też nie wyszedł poza schemat narzucony przez Opatowskiego, gdzie istota opisu hagiograficznego jest możliwie obrazowe, ekspresyjne przedstawienie cnót teologicznych i kardynalnych wyniesionego na ołtarze rodaka. Jedyne novum stanowi kilka dokumentów papieskich i polskich dołączonych na końcu książki.

Curriculum vitae św. Jana Kantego usankcjonowane bullą kanonizacyjną nie doczekało się w w. XVIII żadnej korekty lub uzupełnienia. Różnojęzyczne biografie Świętego napisane po r. 1767 bardziej lub mniej dokładnie powtarzają tekst Żołędziowskiego. Najobszerniejsze z tego czasu jest dzieło J. Putanowicza, wydane in folio w Krakowie (1780). Mamy tu właściwie do czynienia ze zbiorem dokumentów kanonizacyjnych, kazań i hymnów napisanych podczas uroczystości w Rzymie (1767) i w Krakowie (1775). Jedynie na początku (f. A1-H3) mamy życiorys Jana Kantego, powielający w swej strukturze znane już źródła hagiograficzne.

$\mathrm{Na}$ nowe opracowanie tego tematu trzeba było czekać do roku 1862, kiedy to nieoczekiwanie pojawiła się kolejna biografia mistrza z Kęt, tym razem po francusku. Napisała ją panna E. Benoit ${ }^{46}$, zaprzyjaźniona z domem Czartoryskich. Mimo pozorów historycyzmu żarliwe dziełko panny Benoit powtarza w dewocyjnym stylu, podbarwionym wybujałą miejscami wyobraźnią autorki, dzieje Janowego żywota tak, jak je przedstawili poprzedni hagiografowie. Sprawiedliwie jednak trzeba przyznać, że autorka dość gruntownie zapoznała się z odpowiednią literaturą historyczną, co świadczy, że znała język polski i łacinę. O wiele bardziej wartościowy jest przekład polski tej książeczki dokonany prawie 40 lat później przez ks. Juliana Bukowskiego, z okazji 500-letniej rocznicy urodzin Świętego w r. 1890. Ks. Bukowski, gorliwy i sumienny badacz problematyki związanej z osobą Jana Kantego, uzupełnił tekst przekładu rzeczowymi przypisami, których treść czerpie głównie z odnalezionych i skatalogowanych przez Wisłockiego jagiellońskich autografów mistrza Jana. Na ich podstawie koryguje i uzasadnia datę jego urodzin - 24 VI 1390 (s. 10 n.), zestawia spuściznę rękopiśmienną (s. 161-165, 342), próbuje rozwikłać zagadkę przydomka Maleus (s. 338-341), zna akta kanonizacyjne w rękopisach BJ 138 i 139.

$\mathrm{Z}$ autorów polskich $\mathrm{z}$ tego czasu na wzmiankę zasługują jeszcze inni hagiografowie. W stulecie kanonizacji Jana Kantego Domicjan Miecz-

46 Por. E. Benoit, Vie de Saint Jean de Kanti, Paris-Reims 1862. O autorce pisze ks. J. Bukowski we wstępie do polskiego przekładu tej książki (Żywot św. Jana Kantego, Kraków 1890). Sam Bukowski napisał jeszcze artykuł O dacie narodzenia Jana Kantego (Kraków 1889), natomiast ikonograficzną problematyką postaci Świętego zajął się w monografii: Kościół akademicki św. Anny, Kraków 1900. Por. również przypis 53 . 
kowski ${ }^{47}$, drugorzędny historyk i hagiograf, ogłosił niewielką książkę o św. Janie z Kęt, wzorowaną na Vita Opatowskiego. Sam życiorys Kantego obejmuje tu zaledwie 31 stron resztę ponad dwóstustronicowej monografii zajmuje opis cudów, fragmenty z Komentarza do św. Mateusza oczywiście w polskim tłumaczeniu autora ${ }^{48}$, przebieg uroczystości z okazji zakończonej kanonizacji, świadectwa różnych pisarzów o Janie Kantym. Na końcu drukuje trzy hymny znane już z dzieła Putanowicza. Najciekawszym fragmentem książki jest trzystronicowy (s. 16-18) opis rękopisów Jana Kantego. Mieczkowski streszcza tu, zresztą niedokładnie, odpowiedni fragment Summariusza (1730), gdzie, jak wiadomo zostały omówione kodeksy Kantego przywiezione do Rzymu w r. 1728 (s. 28-34) i tam już (do dzisiaj) pozostawione. Od siebie dodał opis trzech rękopisów Jana Kantego spoczywających w zbiorach BJ. Wspominam o tym dlatego, że jest to pierwsze przed Wisłockim omówienie aktualnego stanu rękopisów mistrza z Kęt.

Innego rodzaju jest praca ks. H. Koszutskiego (1889) ${ }^{49}$. Ten proboszcz z Mielżyna parał się hagiografią z wielkim upodobaniem i ambicją naukową, ale z dużo mniejszymi efektami. Książka o Kantym napisana została w oparciu o materiał zebrany przez Putanowicza, choć zna i cytuje innych autorów, z bollandystami i Wisłockim włącznie. Do tej kategorii opracowań tematu o Janie Kantym zaliczyć wypada również prace S. Brzozowskiego, S. Parasiewicza ${ }^{50}$ i innych późniejszych autorów również z naszego już stulecia.

$\mathrm{Na}$ dzisiejszym stanie wiedzy o życiu Jana Kantego zaciążyły jednak dwie diametralnie różne monografie $\mathrm{z}$ w. XIX.

Podstawowy materiał do biografii św. Jana z Kęt został zebrany wówczas poza granicami Polski. Dokonał tego Beniamin Bossue w monumentalnych Acta Sanctorum (October VIII). Metodyczny układ treści artykułu o św. Janie obejmuje osiem rozdziałów: źródła do biografii Świętego (s. 1042-1047), jego życie (s. 1047-1051), dzieje kanonizacji i kultu (s. 1051-1061), autentyczność przypisywanych mu dzieł (s. 1061-1063), Opatowskiego Vita (s. 1064-1073), miracula (s. 1073-1100), miracula zatwierdzone przez Kongregację (s. 1100-1102), bulla kanonizacyjna Klemensa XIII (s. 1102-1106). B. Bossue z wielką sumiennością omawia prace innych autorów zajmujących się osobą Jana Kantego, pod-

47 Por. D. Mieczkowski, Opis życia $i$ cudów św. Jana Kantego, Kraków 1867.

48 Jest to fakt zaskakujący, bo przecież Kongregacja Obrzędów zanegowała (1730) autorstwo Jana Kantego w przypisywanych mu kodeksach — por. M. Rechowicz, $31 \mathrm{n}$.

49 Por. H. Koszutski, Sw. Jan Kanty patron królestwa polskiego, Bytom-Rozbark 1889; F. Swiątek, Z dziejów polskiego żywotopisarstwa świętych, Lublin 1937, $144 \mathrm{n}$.

50 Monografie obu autorów ukazały się pod tym samym tytułem (Żywot św Jana Kantego) i w tym samym roku (1884) w Warszawie i we Lwowie. 
kreśla sprzeczności i niedokładności w podanych przez nich informacjach. Zrozumiałe, że dużą trudność sprawiało mu zebranie i przestudiowanie polskich źródeł hagiograficznych i historycznych. Aby uniknąc dalszych dezinformacji koresponduje $w$ tych sprawach $z$ lwowskimi jezuitami - Józefem Brownem i Mikołajem Baworowskim. W Paryżu zaś osobiście rozmawiał z ks. P. Semenenką na temat języka i wartości monografii Opatowskiego. Dzięki tym poszukiwaniom naukowym Bossue osiągnął w swej pracy wysoki stopień autentyzmu. Omówienie jej w sposób na jaki zasługuje wykracza poza granice niniejszego studium. Wybrałem z niej jedynie pewne kwestie warte, moim zdaniem, choćby pobieżnego wyjaśnienia. Na czoło problemów biograficznych wysuwa się sprawa tajemniczego żywotu, o jakim wspomina w swoich notatkach Bollandus (s. 1044). Dowiodłem w rozdziale poprzednim, że autorem Vita był krakowski jezuita Fr. Schembek. Korespondencja, jaką wymieniał $\mathrm{w}$ tej sprawie $\mathrm{z} \mathrm{H}$. Rosweyem znajduje się $\mathrm{w}$ archiwum bollandystów. Wątpię wszakże czy dotarcie do niej pozwoli rozwikłać zagadkę przydomka Vacenga. Tak czy inaczej, biogram napisany przez Fr. Schembeka gdzieś ok. 1603 roku należy uważać za pierwsze prawdziwie historyczne opracowanie życiorysu Jana Kantego. Poza krytycznym omówieniem głównych danych biograficznych Swiętego (s. 1047-1051), Bossue przedrukowuje Vita Opatowskiego. Jak wiadomo nie miała ona osobnych rozdziałów o cudach, jak to zrobił w późniejszej wersji polskiej. Otóż Bossue dopełnił łaciński tekst wersji pierwszej trzema częściami z wersji polskiej przełożonymi na łacinę w r. 1661 na prośbę Bollandusa. Przekładu tego dokonał Benedykt Boym TJ ze Lwowa. Bollandus bowiem nie znał wydania monografii Opatowskiego z r. 1628 i w tej sprawie korespondował ze swoimi konfratrami z Polski - A. Stredoniusem i A. Tylkowskim (s. 1045), albo też miał nadzieję znaleźć w Żywocie obszerniejszy materiał informacyjny o życiu Jana Kantego.

Pomijając z braku miejsca inne ważne problemy zawarte w artykule B. Bossue, pozostaje nam jedynie stwierdzić, że $\mathrm{z}$ wielu istotnych powodów powinien on zostać dokładnie omówiony. Dysponujemy bowiem bogatym materiałem porównawczym, narosłym wokół dzieł i pisarzy, choćby tylko pobieżnie traktujących o osobie mistrza z Kęt.

Druga z zapowiedzianych wyżej prac dziewiętnastowiecznych o życiu Jana Kantego to wymieniana już kilkakrotnie rozprawa W. Wisłockiego - streszczenie zaginionej obszernej monografii o Janie Kantym ${ }^{51}$. Podany przez autora zestaw wykorzystanych źródeł drukowanych i rękopiśmiennych pozwalał żywić nadzieję, że przygotowany przez Wisłockiego elaborat o życiu i dziejach kanonizacji św. Jana Kantego będzie

51 W. Wisłocki referował ją na czterech kolejnych posiedzeniach wydziału historyczno-filozoficznego Akademii Umiejętności (14 III, 2 V, 13 VI, 1 VII 1890). 
pracą historycznie udokumentowaną tym bardziej, że Wisłocki był dobrym erudytą i, co może najważniejsze, doświadczonym mediewistą. Tymczasem, jeśli nawet uwzględnimy stan ówczesnej wiedzy historycznej i ograniczone możliwości skompletowania odpowiedniej dokumentacji rzeczowej, to i tak trzeba ze smutkiem stwierdzić, że Wisłocki zebrany materiał interpretował często fałszywie, a miejscami nawet humorystycznie (np. fantazyjna dygresja na temat rodziców i wczesnej młodości Jana Kantego - s. 33 n). Nie sposób w tym miejscu poddać gruntownej analizie to wszystko, co dzięki wywodom Wisłockiego tak bardzo w rezultacie zaszkodziło dzisiejszej wersji żywota Jana z Kęt. Największe zamieszanie spowodowała teza, że Jan Kanty urodził się 27 XII 1389 roku w Malcu pod Kętami z ojca Stanisława Wacięgi i matki Anny Sramówny. Za datą urodzin miał przemawiać zapis w kolofonach rękopisu BJ 1216 i Vat. Lat. 14646 (kolofon z tego ostatniego rękopisu znał Wisłocki z odpisu znajdującego się w aktach procesu kanonizacyjnego z w. XVIII - rks BJ 139, f. 5967r.) ${ }^{52}$ Dodatkowym argumentem miała być pieczęć z symbolem Jana ewangelisty, jaką miał używać w dokumentach urzędowych mistrz z Kęt. Te twierdzenia Wisłockiego całkowicie i rzeczowo obalił ks. J. Bukowski ${ }^{53}$, udowadniając ostatecznie, że należy przyjąć datę 24 VI 1390 r.

Problem pochodzenia mistrza Jana jest o wiele bardziej złożony niż to przypuszczał Wisłocki. Główny błąd metodyczny popełnił on zaraz na wstępie przyjmując za zupełnie pewną lekcję z kolofonów zawierających ów przydomek Maleus i de Marta. Wisłocki znał je z siedemnastowiecznych odpisów, gdyż rękopisy, w których one występują, zawędrowały w r. 1728 do Rzymu i tam już pozostały. Do tego w błędnej i bałamutnej argumentacji geograficzno-historycznej uzasadniał synonimiczność nazwy miejscowej Malec i Marta. W ten sposób zmusił niejako Jana Kantego do urodzenia się w Malcu, choć poza owym jedynym kolofonem (dziś w rękopisie BV — Vat. Lat. 14 647, f. 81v), nie przytoczył żadnego innego świadectwa. Natomiast sam Malec nie ma nic wspólnego z ową Martą, która jest po prostu nieporozumieniem paleograficznym ${ }^{54}$, o czym Wisłocki nie mógł wiedzieć, ale nie wolno mu było wysuwać hipotezy, na poparcie której nie miał żadnego dowodu ani geograficznego, ani historycznego.

Podobną wartość naukową ma wywód na temat etymologii nazwiska Wacięga, choć sama nazwa jest z językowego punktu widzenia poprawna, a zatem jej użycie zupełnie realne. Natomiast sugerowane przez Wisłoc-

52 Por. J. Swastek, 178-180.

53 Treść uwag ks. Bukowskiego ukazała się w dodatku clo tych samych Sprawozdań AU, co rozprawa Wisłockiego (s. 57-65). Por. przypis 46.

54 Por. niżej s. 35. 
kiego nazwisko matki Jana Kantego, jest bezpodstawnym wymysłem autora. Rzeczowa kontrargumentacja zajęłaby nam zbyt dużo miejsca.

$\mathrm{Na}$ podstawie tego, co powiedziałem o rozprawie Wisłockiego, nie chciałbym, aby Czytelnik nabrał przekonania, że jest ona zupełnie bezwartościowa. Byłoby to z pewnością krzywdzące dla autora. Jej wada jest wszakże to, że autor z niepewnych lekcji popartych bardzo niepewnymi argumentami wyciąga kategoryczne konkluzje, nie podlegające żadnej dyskusji. Widać to już z samego tytułu rozprawy. Tymczasem trzeba z całym naciskiem podkreślić, że w poruszonych przez nas kwestiach ani względy historyczne, ani filologiczne, ani nawet legendarna tradycja w najmniejszym stopniu nie potwierdzają hipotez Wisłockiego. Ze zdziwieniem przeto przychodzi nam stwierdzić, że mimo tak oczywistych wątpliwości, narzucających się samorzutnie każdemu historykowi, biograficzne pomysły Wisłockiego pokutują do dziś w publikacjach popularnych i naukowych, poświęconych w jakimś stopniu osobie św. Jana z Kęt.

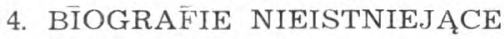

$\mathrm{Na}$ koniec tych naszych rozważań o narracyjnych źródłach do biografii Jana Kantego chciałbym powiedzieć parę słów o nieistniejących, a cytowanych opracowaniach jego życiorysu.

Już B. Bossue wykluczył prawdopodobieństwo edycji żywotu Jana Kantego pióra Marcina Bielskiego ${ }^{55}$. Również P. Skarga nie napisał nigdy takiego żywotu po łacinie, a tylko opracowany przez niego po polsku biogram Jana Kantego przełożono na łacinę w toku procesu beatyfikacyjnego ${ }^{56}$. W pierwszej połowie XIX w. Adrian Krzyżanowski napisał jakąś Rzecz o życiu $i$ kanonizacji Jana Kantego. Manuskrypt tej nigdy nie wydanej pracy był własnością Biblioteki Uniwersytetu Warszawskiego i podzielił los innych rękopisów warszawskich, zniszczonych częściowo w Rostowie w czasie I wojny światowej lub spalonych w Warszawie w r. $1944^{57}$. Cytowane w łacińskim artykule A. Arndta SJ 58 dwa biogramy polskie zostały w istocie wydane dopiero w r. 1767 (Życie św. Jana Kantego = Vita s. Joanni Cantii) i w r. 1768 (Opis życia = Descriptio vitae). Natomiast ani w Bibliografii polskiej K. Estreichera, ani w bibliotekach krakowskich nie znalazłem potwierdzenia wiadomości E. Iwanowskiego ${ }^{59}$ jakoby o życiu Kantego ogłosili swe prace Andrzej Bie-

$5 \overline{5}$ Por. B. Bossue, 1043, 1045.

56 Por. Summarium (1675), 104-110.

57 Por. H. Kozerska, Straty $w$ zbiorze rękopisów Biblioteki Uniwersyteckiej $w$ Warszawie, w czasie I i II wojny światowej, Warszawa 1960, 77.

58 Por. A. Arndt, De loco et anno nativitatis nec non de anno obitus et reliquiis s. Joannis Kant, ,Analecta Bollandiana”, t. VIII: 1889, 382-388.

59 Por. E. Iwanowski, Wspomnienia polskich czasów dawnych $i$ późniejszych J.wów 1894. T. I, 45. 
chowski (1707) i Ambroży Nieszporkiewicz (1672). Zabawnego zaś figla spłatał biografom Świętego J. Bartoszewicz swoją trzytomową publikacją o wybitniejszych osobistościach polskich z XVIII wieku ${ }^{60}$. Otóż w tomie II tego dzieła poświęcił jeden rozdział trzem braciom Moszyńskim, z których najstarszy, noszący popularne wonczas podwójne imię - Jan Kanty - nie ma nic wspólnego ze swoim świętym patronem, jako że ożeniony z Fryderyką Augustą de Cosel, naturalną córką Augusta II, był nie tylko zięciem tego ostatniego, ale i nadwornym podskarbim. Jeśli nawet L. Finkel ${ }^{61}$ uznał Bartoszewicza za kolejnego biografa Jana z Kęt, nie można się dziwić, że cytują tę pozycję mniej doświadczeni hagiografowie.

\section{UWAGI OGOLNE}

Analizując materiał narracyjny do biografii św. Jana z Kęt możemy stwierdzić, że określone jej elementy nawiarstwiały się stopniowo w ciągu minionych stuleci.

Najstarsze świadectwa (Długosz, Tauchen, Schedel) mówią o świętości i cudach profesora krakowskiego, pochowanego w kościele akademickim św. Anny, wspominają też o jego pielgrzymkach do Rzymu i Ziemi Świętej. Nie utrzymało się natomiast ani w biografii, ani w tradycji śląskie pochodzenie Kantego, podtrzymane w wiekach późniejszych jedynie w pracach Curaeusa, Hanckego i B. Bossue. Data śmierci (24 XII 1473) pojawia się dopiero w epickiej Vita servi Dei Ioannis Cantii, na podstawie której opracował jego biogram Maciej z Miechowa w swojej Kronice Polaków. Rozpowszechnienie dzieła Miechowity utrwaliło w pracach następnych autorów te właśnie elementy biograficzne mistrza z Kęt. Początek wieku XVII przyniósł nowe dane do jego życiorysu. $\mathrm{Z}$ biogramów opracowanych przez Schembeka i Skargę znamy imiona rodziców Świętego oraz dalszą ilość cudów. Starowolski pierwszy wymienia cztery kodeksy z autografami mistrza z Kęt, Opatowski zaś ustala datę jego urodzin. W trakcie zbierania materiałów do przewodu beatyfikacyjnego natrafiono na dalsze kodeksy Kantego, tak że z początkiem w. XVIII znano już 11 woluminów, z czego 10 wysłano do Rzymu w r. 1728, by stamtąd ich już nie odebrać. W tym też czasie wyszła na jaw sprawa rektorstwa Jana Kantego w szkole klasztornej w Miechowie, o czym np. jeszcze nie wiedział zupełnie Nakielski, wspominając o Janie Kantym z przyczyn zupełnie innych. Do czasu badań Wisłockiego i ks. J. Bukowskiego nie dokonano prawie żadnych korektur w życiorysie

60 Por. J. Bartoszewicz, Znakomici mężowie polscy $w$ XVIII wieku, Petersburg 1856 , t. II.

61 Por. L. Finkel, Bibliografia historii polskiej, Warszawa 1956, 26993 oraz w indeksie osób pod hasłem: Jan Kanty. 
Janowym. Wisłocki pierwszy wykorzystał odnalezione przez siebie autografy mistrza z Kęt, ale opracowana przez niego rozprawa nie zadowoliła nawet mało obeznanych z przedmiotem historyków. Trzeba było znowu czekać z górą pół wieku, aby w pracach ks. Rechowicza i innych autorów znaleźć nowe wiadomości i rozszerzyć zasięg naszej wiedzy w zakresie biografii Jana z Kęt.

\section{SPUŚCIZNA RĘKOPIŚMIENNA SW. JANA Z KĘT}

Zbiór kodeksów zgromadzonych przez Jana Kantego liczy dziś 27 woluminów. Jest to kolekcja szczególna, gdyż niemal w całości wyszła spod jego pióra. Jako kopista pracował nad skompletowaniem tego zbioru około lat 40. Jak wiele innych profesorskich bibliotek $\mathrm{z}$ w. XV, również ta powiększyła po śmierci swego właściciela księgozbiór uczelni ${ }^{62}$. W tym miejscu nasuwa się jednocześnie pytanie i wątpliwość czy kolekcja Janowa $\mathrm{w}$ swym obecnym stanie odtwarza zespół pierwotny, powiedzmy według stanu liczbowego na dzień 24 grudnia 1473 roku. Trudno bowiem pogodzić się z myślą, że Jan Kanty posługiwał się w swej pracy dydaktycznej wyłącznie książkami przez siebie skopiowanymi. Zresztą nikłe ślady jego zainteresowań, czy raczej skłonności bibliofilskich, utwierdzają nas w przekonaniu o istnieniu znacznie bogatszej jego prywatnej biblioteki od tej, jaka przetrwała do naszych czasów ${ }^{63}$. Niczego jednak nie możemy powiedzieć na temat kodeksów, których istnienia zaledwie się domyślamy. Nie wiemy też czy Jan Kanty jakimś osobnym dokumentem legował swoje książki na rzecz uniwersytetu lub innych instytucji czy osób prywatnych ${ }^{64}$. Sądzę, że tych adresatów było kilku i niekoniecznie weszli $\mathrm{w}$ posiadanie Janowych kodeksów dopiero po jego śmierci.

Zainteresowanie autografami Jana $z$ Kęt nie rozbudziło się jednocześnie $z$ rozwojem kultu jego osoby. Rękopisy te przeleżały spokojnie ponad 130 lat na półkach biblioteki Collegium Większego, aż z począt-

62 Por. HistBJ, 95 n. Zbiór rękopisów Jana Kantego nie znalazł natomiast uznania w oczach Wł Szelińskiej, która jedynie w przypisach wspomniała imię Swiętego - por. W. Szelińska, Biblioteki profesorów Uniwersytetu Krakowskiego w XV i na poczatku XVI wieku, Warszawa 1966, 45, 51, 138.

63 W tym przypuszczeniu umacnia nas rkps BJ 325 (por. R. Zawadzki, Lektura) $i$ Vat. Lat. 14643 . Natomiast z rękopisu BJ 2718, zatytułowanego Rationale seu conscriptio omnium rerum collegiatae ecclesiae divae Annae Cracoviae (1552) dowiadujemy się, że inter antiqua missalia sunt duo breviaria et tertium antiquum beati Joannis Cantii etiam ex pergameno (f. 47r).

64 Np. rkps 1216 przeznaczony zostal dla Collegium Maius; rkps 2375 miał w swojej bibliotece Jakub z Lisowa, z którym nb. Kanty pełnil funkcje prepozyta Collegium Większego w r. 1472 (por. HistBJ, 41); wreszcie rkps Vat. Lat. 14647 oddał Jan Kanty kościołowi św. Andrzeja w Olkuszu, gdzie nominalnie był proboszczem przez dwa miesiące. 
kiem w. XVII dotarł do nich jako pierwszy Fr. Schembek podczas zbierania materiałów do życiorysu Jana Kantego ${ }^{65}$. Dalsze ich poszukiwania wzmogły się od chwili, kiedy S. Starowolski ogłosił w Setniku pisarzów polskich, że Jan Kanty jest autorem Komentarza do św. Mateusza i tomu kazań. W wyniku kwerendy przeprowadzonej w latach 60-tych tegoż stulecia odnaleziono 10 woluminów i poddano je próbnym badaniom ${ }^{66}$. Trudności paleograficzne przewyższały jednak dość nikłe umiejętności ówczesnych notariuszy i ci zdołali zaledwie odczytać kilka kilofonów oraz opatrzyć tytułami poszczególne tomy bardziej na zasadzie domysłu niż po rzeczywistym zapoznaniu się z treścią sygnowanego kodeksu. Te tytuły i kolofony wciągnięto do protokołów beatyfikacyjnych, skąd późniejsi badacze usiłowali wydobyć jak najwięcej informacji o domniemanych dziełach Kantego, gdyż same kodeksy były niedostępne ${ }^{67}$. W połowie w. XVII odpisu doczekał się jedynie Komentarz do św. Mateusza. Kopię tę sporządził M. Radymiński, a już na podstawie tego odpisu powstała inna $\mathrm{w}$ latach 1687 -1693. Obie kopie powstały $\mathrm{w}$ toku procesu beatyfikacyjnego i kanonizacyjnego. Istniało bowiem przypuszczenie, że Komentarz jest największym dziełem tego kandydata na ołtarze, wobec czego należy je poddać badaniom poprawności doktrynalnej. Cenzura ta została przeprowadzona w Rzymie. W r. 1693 zakończono w Krakowie przewód kanonizacyjny, akta procesu złożono w archiwum kolegiaty św. Anny, a ich transumpt posłano do Rzymu. Z polecenia Kongregacja Obrzędów trudnej roli cenzora podjął się Karol de Valesio, penitencjarz kościoła św. Jana na Lateranie. W przygotowanym przez niego referacie wytknięte zostały przede wszystkim tezy koncyliarystyczne, rozrzucone po całym Komentarzu. De Valesio przedłożył Kongregacji swój raport 2 kwietnia $1703 \mathrm{r}$. Z niewiadomych jednak powodów jeszcze w czerwcu 1698 r. Kongregacja ponownie zarządała od biskupa krakowskiego przesłania nowego transumptu akt, gdyż poprzedni miał zaginąć w Rzymie. Prace nad nowym transumptem potrwały do roku 1716. Kiedy ten w końcu znalazł się w Rzymie zdążono już zapomnieć o recenzji K. de Valesio i badania nad poprawnością doktrynalną Komentarza rozpoczęto od nowa ${ }^{68}$. Charakter koncyliarystyczny domniemanego dzieła Jana Kantego potwierdzał się w całej rozciągłości, a jednocześnie dotarła do Rzymu (ok. 1725) wiadomość z Krakowa, że odnaleziono nowy rękopis Kantego, zawierający teksty z czasów soboru bazylejskiego. Rygorystycznie usposobiony kardynał ponens Pico de Mirandola nakazał przysłanie do Rzymu wszystkich rękopisów Jana z Kęt oraz

65 Swiadectwo o tym daje P. Skarga w biogramie Jana Kantego - por. przypis 29 .

66 Por. M. Rechowicz, 16-24.

67 Por. J. Swastek, 159 n; Summarium (1730), 28-34.

68 Por. R. M. Zawadzki, 10; por. rks BJ 5787. 
odpowiednich dokumentów stwierdzających jego działalność uniwersytecką. Władze Uniwersytetu Krakowskiego posłusznie zastosowały się do życzenia Kongregacji i w r. 1728 przez specjalnego portitora wysłano 10 woluminów, znanych już dawniej $\mathrm{z}$ akt procesowych, oraz Liber promotionum, pergaminową listę z XVI w. z wykazem profesorów krakowskich i kopię Komentarza, sporządzoną ongiś przez M. Radymińskiego. Zatrzymano natomiast na miejscu niewygodny rękopis bazylejski (dziś BJ 414), utrzymując, że jego autorem był inny Jan z Kęt ,koncyliarysta”, młodszy krajan naszego Patrona ${ }^{69}$. Już w r. 1730 Kongregacja wydała oficjalne orzeczenie stwierdzające, że nie ma żadnej pewności iż Jan Kanty był autorem któregokolwiek z dostarczonych rękopisów. Werdykt Kongregacji potwierdzony w bulli Klemensa XIII (1767) do tego stopnia osłabił zainteresowanie Janowymi kodeksami, że A. Żołędziowski, wracając z Rzymu z bullą kanonizacyjną zapomniał zabrać kodeksy złożone przed 40 laty w siedzibie Kongregacji. Nigdy też one do Krakowa już nie powróciły.

Porządkowanie zbiorów BJ za dyrektury S. Bandkiego (1811-1835) i J. Muczkowskiego (1837-1858) ujawniło 5 nieznanych dotąd autografów mistrza z Kęt, o czym mamy wiadomość u Mieczkowskiego i H. Zeissberga ${ }^{70}$. Dopiero jednak opracowany przez Wisłockiego i do dziś niezastąpiony Katalog rękopisów BJ pozwolił skompletować obecną kolekcję rękopisów Jana z Kęt. Jak już wspomniałem zajął się nią najpierw sam W. Wisłocki, ale nie potrafił należycie wykorzystać materiałów tam zawartych. Niemal równolegle ogłosili swe prace A. Arndt i J. Bukowski, lecz zajęli się oni prawie wyłącznie rękopisem BJ 1216. Jeszcze pewne wiadomości o rękopisach Jana Kantego znalazły się w fundamentalnych dziełach J. Fijałka ${ }^{71}$ i K. Morawskiego ${ }^{72}$, ale to już były ostatnie w tych czasach poważne w tej materii publikacje. Po ostatniej wojnie stosowne studia nad rękopisami Kantego rozpoczął właściwie dopiero M. Rechowicz $^{73}$. Z jego zaś inspiracji J. Swastek zajął się kapitalnym zagadnieniem z zakresu tych rękopisów, a mianowicie występującymi w nich kolofonami. Choć artykuł ks. Swastka wymaga wielu korektur i uzupełnień (autor nie wykorzystał wszystkich kolofonów z rękopisów BJ), choć można by mieć zastrzeżenia co do obranej metody w referowaniu

69 Powody tej ciecyzji wyjaśniam w powyższym artykule (s. 12). Por. też: M. Rechowicz, 28; W. Wisłocki, 21.

70 Wymieniają oni rękopisy Jana Kantego pod nieistniejącymi dzisiaj sygnaturami, - por. wyżej przypisy 26, 47.

71 Por. J. Fijałek, Studia do dziejów Uniwersytetu Krakowskiego $i$ jego wydziału teologicznego w XV wieku, Kraków 1898, 151-160; Mistrz Jakub z Paradyża $i$ uniwersytet krakowski w okresie soboru bazylejskiego, Kraków 1900. T. I, 10.

72 Por. K. Morawski, Historia Uniwersytetu Jagiellońskiego, Kraków 1900. T. I, $419-421$.

73 Tytuły ogłoszonych od tego czasu prac o Janie Kantym wyszczególniono w Hp I, 551. Por. J. Swastek, 156 i passim. 
materiału itp., to jednak trzeba podkreślić jego pionierski charakter w naszej literaturze mediewistycznej i dużą wartość poznawczą. Inne cele przyświecały M. Markowskiemu w jego pracach nad filozoficzno-przyrodniczymi komentarzami z w. XV ${ }^{74}$. Na marginesie prac przygotowawczych do nowego katalogu rękopisów średniowiecznych BJ powstały artykuły Z. Siemiątkowskiej ${ }^{75}$ i autora niniejszej rozprawy ${ }^{76}$. Oczywiście spotyka się jeszcze inne publikacje, gdzie można znaleźć wzmianki o rękopisach Jana Kantego i ich zawartości. Są one tylko przyczynkiem do poznania całości jego kolekcji rękopiśmiennej 77.

Szczególne zainteresowanie mediewistów kodeksami Jana z Kęt rozbudziło się ostatnio na nowo $\mathrm{z}$ powodów równie osobliwych co niespodziewanych. Bynajmniej nie była nim przypadająca w grudniu bieżącego roku pięćsetna rocznica śmierci patriarchy krakowskiego, ale wiadomość, która z początkiem tegoż roku dotarła do Krakowa ${ }^{78}$. Oto wywiezione przed 250 laty autografy Jana Kantego zostały ,odnalezione" tam, gdzie je wtedy złożono, tzn. w rzymskiej Kongregacji Obrzędów. Dokonano tego odkrycia, kiedy część archiwaliów Kongregacji została przekazana Bibliotece Watykańskiej. Wśród nich znalazły się kodeksy Jana Kantego oraz Radymińskiego transumpt Komentarza do św. Mateusza.

W tym miejscu muszę poświadczyć z uczuciem najserdeczniejszej wdzięczności, że dzięki życzliwej i jak zwykle skutecznej pomocy J. Em. Ks. Kard. Karola W o jtyły, doceniającego ważność tego naukowego ewenementu, mogłem sprowadzić mikrofilmy z watykańskich autografów Jana Kantego i poddać je naukowym badaniom ${ }^{79}$.

${ }_{74}$ Por. M. Markowski, Wptyw burydanizmu na Uniwersytet Krakowski w pierwszej połowie XV wieku [w:] Z dziejów filozofii na Uniwersytecie Krakowskim w XV wieku, Warszawa 1965, 129, 137; Burydanizm w Polsce $w$ okresie przedkopernikańskim, Warszawa 1971, 2-26, 305-377, 504-533.

75 Autorka sporządziła dla Instytutu Filozofii PAN opisy katalogowe następujących rękopisów BJ: 1690, 1691, 2078, 2206, 2371, 2376. Ponadto oddała do dyspozycji tegoż Instytutu maszynopis artykułu o Janie Kantym. Wykorzystał tę prace J. Swastek.

76 Poza artykułami cytowanymi w niniejszej rozprawie opracowałem również dla tejże instytucji opisy następujących rękopisów związanych z osobą mistrza z Kęt: 105, 325, 1216, 1375, 2369, 2372, 2375, 2377, 2603, 2724. Rkp. 414 opisał M. Zwiercan.

77 Najwięcej wzmianek o rękopisach Jana Kantego znajdujemy w czasopismach wydawanych przez Instytut Filozofii PAN, a mianowicie: „Studia mediewistyczne”, „Materiały i Studia Zakładu historii filozofii starożytnej i średniowiecznej".

78 Wiadomość tę zawdzięczam Kierownikowi Oddziału Rękopisów BJ doc. dr J. Zatheyowi, który przywiózł ją z Włoch, gdzie na przełomie roku 1972/3 bawił w podróży naukowej. Z pomocą zaś Instytutu Studiów Kościelnych w Rzymie zrealizowałem zamówienie na mikrofilmy tych rękopisów. BV. Obu pośrednikom składam w tym miejscu serdeczne wyrazy podziękowania.

79 Pierwszą wiadomość o watykańskich rękopisach Jana Kantego ogłosiłem w artykule: Watykańska kolekcja rękopisów św. Jana z Kęt, ,Ruch Biblijny i Liturgiczny" (1973) $\mathrm{nr}$ 5/6, $1 \mathrm{nn}$. 
Z mnogości zagadnień związanych z kolekcją rękopisów św. Jana z Kęt wybrałem jedynie te, których omówienie pozwoli Czytelnikowi wyrobić sobie ogólny pogląd na całość warsztatu naukowego mistrza Jana, na sposób jego pracy, na rodzaj zainteresowań intelektualnych. W tym celu zostanie omówiony obecny stan tej kolekcji, czas powstania poszczególnych rękopisów lub ich części, wreszcie zawartość merytoryczna.

1. CHARAKTERYSTYKa ILOŚSIOWA I PROWENIENCYJNA KOLEKCJI.

Omawiane kodeksy Jana Kantego tworzą dziś zbiór złożony z 27 woluminów. Pośrednio łączą się z nimi siedemnasto- i osiemnastowieczne kopie Komentarza do św. Mateusza. Cała ta kolekcja, tworząca niegdyś jedną całość biblioteczną, została z czasem rozbita na dwa zespoły jagielloński i watykański. Z istnienia zespołu autografów Jana Kantego w BJ nie zdawano sobie sprawy do połowy wieku XIX. Zespół watykański utworzyły rękopisy wywiezione z Krakowa w r. 1728 i oddane do dyspozycji Kongregacji Obrzędów. Poniżej zestawiam aktualne sygnatury obydwóch zespołów. W nawiasie podaję daty roczne, umieszczone przez kopistę w kolofonach danego rękopisu, a w wypadku ich braku podaję z pytajnikiem przypuszczalny rok powstania manuskryptu. Przy sygnaturach BV dodaję dawne tytuły tych kodeksów, pod jakimi je znaliśmy do tej chwili.

a. Autografy św. Jana z Kęt:

Zbiór BJ

$325(1434)$

414 (?1437-1440?)

$1216(1455-1456)$

1375 (1445?)

$1690(1452,1454)$

$1691(1457)$

2078 (1435)

2206 (1458?)

2369 (?1430-1433?)
Zbiór BV

Vat. Lat. 14182 „Manuale sermonum dominicalium" (1430?)

Vat. Lat. 14638 ,Quaestiones de veritate $s$. Thomae de Aquino" (1447-1448)

Vat. Lat. 14641 „Prima pars super Matthaeum" (1450?)

Vat. Lat. 14642 „Glossae super Evangelia" (1426?)

Vat. Lat. 14643 „Commentaria super librum Sapientiae" (1446) 


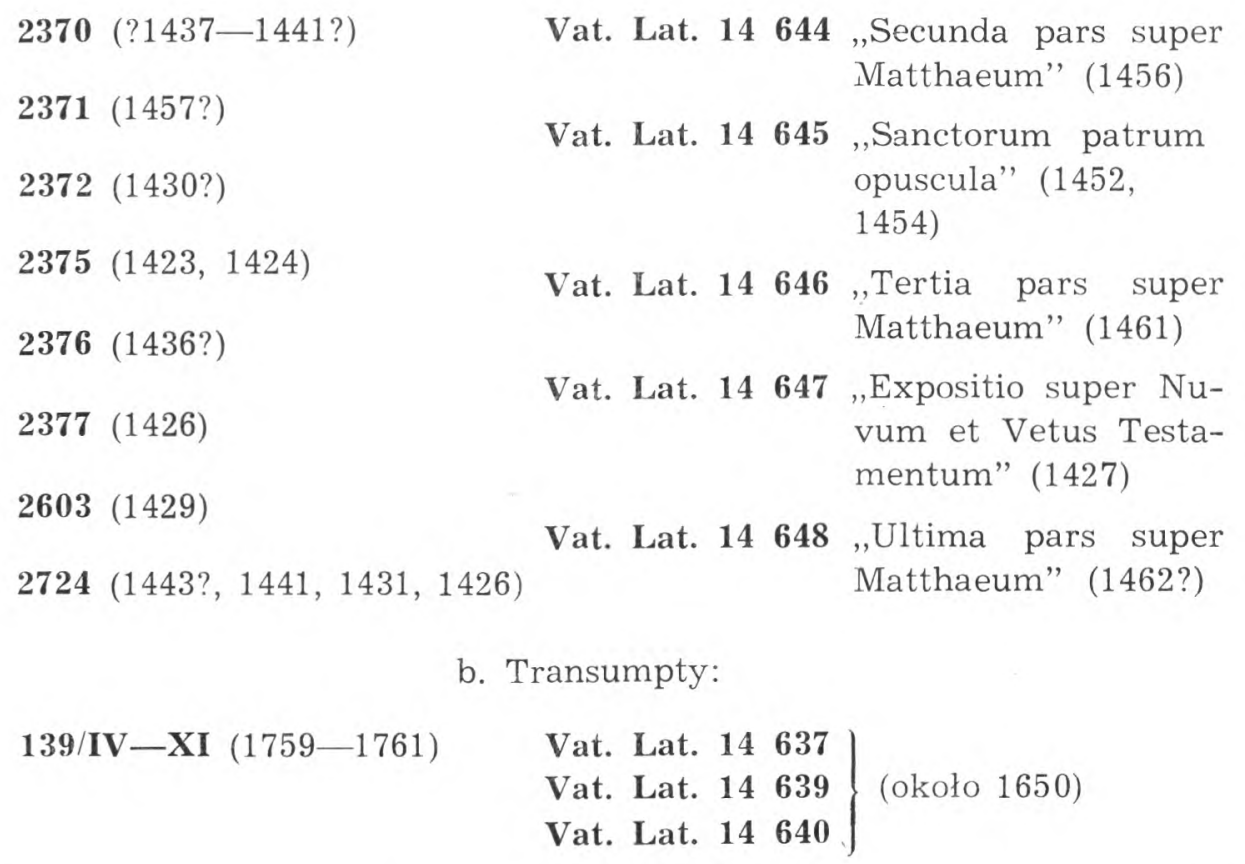

W powyższym wykazie pominięto rękopis BJ 760. Wisłocki sugerował jego przynależność do grupy autografów Jana Kantego wyłącznie na podstawie względnego podobieństwa pisma. Chodzi tu zresztą o końcowy register do kwestii quodlibetycznych Tomasza z Akwinu. Analiza paleograficzna całkowicie podważa hipotezę Wisłockiego ${ }^{80}$. Rękopis Vat. Lat. 16642 jest jednym z najstarszych w kolekcji Jana Kantego, ale udział w nim mistrza z Kęt jako skryptora jest dosłownie marginalny, gdyż sprowadza się do gloss i notatek umieszcznych przez niego na marginesie tekstów nowotestamentowych przepisanych przez byłych studentów krakowskich - Czesława de Vneyne (1425) i Jana z Warty (1423) ${ }^{81}$. Przypuszczam, że Jan Kanty wszedł w posiadanie tego kodeksu nie wcześniej jak około roku 1426. Nie uwzględniłem rękopisu BJ 2230, z którego J. Swastek wypisał nawet kolofon ${ }^{82}$. Tymczasem ten komentarz do Sentencji Piotra Lombarda wyszedł spod pióra Jana ze Słupczy i nigdy nie należał do biblioteki Jana Kantego, nie mówiąc już o tym, że nie mógł być przez niego przepisany ${ }^{83}$. Nie wiem, jakimi kryteriami kierował się tutaj J. Swastek, skoro nie mógł się w tym wypadku powołać na

${ }^{80}$ Rękopis ten z r. 1460 należał do Macieja z Kobylina, doktora dekretów i teologii, dziewięciokrotnego rektora UJ - por. HistBJ, 111. J. Swastek wcielił bez żadnych zastrzeżeń ten kodeks do Janowej kolekcji (s. 160).

81 Por. M. R. Zawadzki, 17.

82 Por. J. Swastek, 165, 198.

83 Por. HistBJ, 104. 
Katalog Wisłockiego. Jak jednak przysłowiowa złośliwość rzeczy martwych może zaciążyć na wynikach przeprowadzonych badań naukowych, tego niezwykłym przykładem jest rkps BJ 2724. Wisłocki dał jego poprawny opis w swoim Katalogu, wynotował kolofony i stwierdził bezsporną autentyczność autografu Jana Kantego. Tymczasem złośliwy chochlik sprawił, że sygnatura tego kodeksu nie znalazła się ani w indeksie Katalogu, ani we wstępie do niego, gdzie (s. II) zestawia Wisłocki wszystkie sygnatury rękopisów Jana Kantego. W ten sposób niby znany kodeks przepadł znowu na lat kilkadziesiąt i dlatego ciągle dotąd powtarzano, że jagielloński zbiór autografów mistrza z Kęt liczy 16 woluminów ${ }^{84}$. Oczywiście nie uwzględnił tego rękopisu J. Swastek i nie został też wymieniony w tematycznej bibliografii do św. Jana z Kęt w I tomie Hp. Można więc żartobliwie powiedzieć, że w pięćsetną rocznicę śmierci Jana Kantego odnaleziono nie tylko 10 woluminów z jego autografami w BV, ale również jeden kodeks w zbiorach Uniwersytetu Krakowskiego. Transumpty ograniczają się tylko do Komentarza Ewangelii według św. Mateusza. W naszym przedmiocie jest to zagadnienie całkiem uboczne i nie będziemy się nim więcej zajmować.

\section{CHRONOLOGIA RĘKOPISÓW Z KOLEKCJI JANA KANTEGO}

Aby ustalić czas powstania poszczególnych kodeksów Jana Kantego należy uwzględnić pewne właściwości jego metody skrypturystycznej. Najbardziej charakterystyczną cechą jest to, że pisał on poszczególne teksty na składkach, łączonych dopiero po jakimś czasie w jeden kodeks. Jak się okazuje musiały one nawet przez kilka lat leżeć złożone w jakimś miejscu nim w końcu właściciel oddał je do introligatora. Ta rozpiętość czasowa między przepisaniem pojedyńczych składek a ich oprawą powodowała wcześniejsze pomieszanie ich kolejności chronologicznej. Że tak było istotnie, utwierdzają nas datowane kolofony, oznaczenia z cisiojanusa rozsiane po kartach wielu kodeksów, ale też cechy zewnętrzne składek, jak zmiana w kolorze atramentu, grubości pióra, rodzaju papieru itp. Nie można natomiast przyjmować bezkrytycznie podanych przez kopistę dat, gdyż zdarzyły mu się pomyłki w postaci mylnie oznaczonego roku (np. w rękopisie BJ 1216 i Vat. Lat. 14 447).

Uwzględniając te wszystkie uwarunkowania, zestawiam w porządku chronologicznym autografy Jana Kantego. Za podstawę biorę nie cały koidekss, ale jego części, o ile były one przepisane w różnym czasie i istnieją przesłanki określenia terminu, w jakim opuściły skryptornię Kantego. Ponieważ daty dzienne oznaczał czasem kopista sylabami cisio-

84 Jedyną o nim wiadomość znalazłem we wstępie E. Dąbrowskiego do: J. Flawiusz, Dawne dzieje Izraela - Antiquitates Iudaicae, Warszawa 1962. 
janusa, przeto podaję ich zapis cyfrowy w następującej formie: np. „,in pede Cris Pan" = 27/31 V. Zdarza się, że w kodeksie występuje tylko jedna data dzienna, czasem bez roku. Wówczas podaję ją w nawiasie, jako termin orientacyjny. Jeśli brak daty rocznej, restytuuję ją opatrzywszy pytajnikiem. Nie ustalam chronologii kart ochronnych, zazwyczaj pergaminowych, pochodzących z XIII-XV w. Nie biorę téz pod uwagę początkowych lub końcowych kart kodeksu albo jego części, na których to kartach pomieścił kopista luźne zazwyczaj notatki. Mogły i były one zapisywane w najrozmaitszym czasie, jako że Jan Kanty często po latach wracał do niegdyś przepisanych przez siebie traktatów. Gdy chodzi o miejsce powstawania poszczególnych rękopisów, przyjmuje się, że od roku 1422 do 1428 kopista przebywał w Miechowie jako kierownik tamtejszej szkoły klasztornej, toteż wszystkie rękopisy z tego okresu musiały również zostać sporządzone w klasztorze bożogrobców miechowskich. Jednakże tylko dwa kodeksy wymieniają w kolofonach tę miejscowość (BJ 2375, Vat. Lat. 14 647).

1423, ante 13 II - post 31 III:

1424 , $19 / 21 \mathrm{X}$ - post $16 \mathrm{XII}$ :

1426 ,

1426 ?,

1426 ?,

1626 ,

1427 ,

1428 ,

1429 ,
$?-21 \mathrm{~V}$ :

(post $21 \mathrm{~V}$ ?):

(19 XI):

$(27 / 31 \mathrm{~V} ; 5 \mathrm{~V})$ :

$?-9 \mathrm{~V}$ :

12/14 VIII - 8 XI:

$?-16$ III:
BJ 2375, f. $1-86$

f. $87-256$

BJ 2724, f. $279-29085$

f. $291-302$

Vat. Lat. 1464286

BJ $2377^{87}$

Vat. Lat. 14647 , f. $1-106^{88}$

f. $107-177 \mathrm{r}$

f. $177 \mathrm{v}-20089$

BJ 260390

85 Klocek rękopiśmienny zawierający teksty $z$ lat $1426-1443$ ze składkami zapisanymi przez innego kopistę (f. 159-182) - por. niżej przypisy 94, 100.

${ }_{86}$ Data marginalna $19 \mathrm{XI}$ na f. $113 \mathrm{r}$. W kodeksie tym ręką Jana Kantego zapisane zostały tylko karty $1-8,17-20,286-295$. Zasadniczą treść kodeksu tworzą teksty Nowego Testamentu przepisane przez dwóch kopistów: f. $21-113 \mathrm{r}$ skopiowal Czechoslaus de Vneyne (7 IX - 23 XI 1425), f. $113 \mathrm{v}-285$ Jan z Warty (1422 - 3 III 1423). Kanty (?) opatrzył te teksty glossą marginalną i interlinearną szczególnie przy listach św. Pawła (f. 113-209).

${ }_{87}$ Rok i pierwsza data dzienna na f. 1r, druga - f. 167r. Jednakże rks składa się co najmniej z 4 części przepisanych w różnym czasie i nie w tej kolejności, jak występują one w kodeksie $(1-24,25-96,97-230,231-308)$.

${ }_{88} \mathrm{~W}$ kolofonie na k. $81 \mathrm{v}$ data $9 \mathrm{~V} 1427$ - Ioannes Maleus alias Kanthy. Por. wyżej s. 25.

89 W kolofonie (f. 197r) podany jest r. 1427, ale data dzienna wskazuje że chodzi tu o rok następny (feria III post dominicam Laetare alias in vigilia Gertrudis). W r. 1427 wigilia św. Gertrudy wypadała w niedzielę Reminiscere (16 III), zaś wtorek po niedzieli Laetare (1 IV).

90 Kodeks składa się z dwóch części. Do f. $74 \mathrm{r}$ mamy traktaty św. Augustyna z datowanymi kolofonami. Resztę kart zapełniają ekscerpty ze św. Tomasza, Piotra z Tarantazji, Bartłomieja z Pizy i in. W tej części mamy tylko jeden kolofon (f. 267r) z datą lipcową tegoż roku.. 


\begin{tabular}{|c|c|c|}
\hline $1430 ?$ & $(2 \mathrm{~V}):$ & BJ 237291 \\
\hline $1430 ?$ & - $1433 ?:$ & Vat. Lat. $14182^{92}$; BJ $2369^{93}$ \\
\hline 1431: & & BJ 2724, f. $267-27894$ \\
\hline 434. & & BJ 325 , f. $1-112^{95}$ \\
\hline & ante $25 \mathrm{VI}$ - post 19 VIII: & BJ $2078^{96}$ \\
\hline $136 ?$ & $?-2$ VIII: & BJ $2376^{97}$ \\
\hline & - $1440 ?:$ & BJ $414 ; 237098$ \\
\hline $\begin{array}{l}441 \\
443 ?\end{array}$ & $\begin{array}{r}\text { ante } 28 \text { VI }-6 \text { VII: } \\
(8-11 \mathrm{X}):\end{array}$ & $\begin{array}{r}\text { BJ 2724, f. } 178-266^{99} \\
\text { f. } 1-157^{100}\end{array}$ \\
\hline
\end{tabular}

91 Data 2 V występuje w jedynym kolofonie (f. 193r), nie uwzględnionym zresztą przez J. Swastka. Rks powstał już w Krakowie, gdzie Kanty zetknął się m. in. ze swoim nauczycielem(?) Janem Elgotem, autorem kazania na cześć królowej Jadwigi (f. $219 \mathrm{v}-226$ ), wygłoszonego w r. 1428.

92 Rękopis umieszczam w tym samym czasie co pozostałe zbiory kazań Jana Kantego, li tylko na podstawie podobieństwa formalnego i merytorycznego, por. przypis 93 .

93 Rks jest zbiorem kazań głównie Mikołaja z Kozłowa i Mikołaja Scultetusa. Składki tego rękopisu zapisane zostały z początkiem lat 30 -tych XV w., ale oprawą zajął się Kanty dopiero po r. 1439. Tę hipotezę stawiam na podstawie następujących przesłanek. Kazanie wygłoszone na egzekwiach księcia Witolda (f. $180 \mathrm{sq}$ ) mogło być napisane po $27 \times 1430$ (data śmierci Witolda). W latach 1434-1436 kopiował Kanty rękopisy BJ 325, 2078, 2376. Z notatek zamieszczonych na wolnych kartach rksu 2369 wynika, że Mikołaj z Kozłowa był w tym czasie jeszcze w Krakowie (f. 260v: Nihil habeo de passione Domini a magistro Koszlowsky). Wiemy zaś, że od 1433-1437 Kozłowski (wraz z Mikołajem Lasockim) przebywał na soborze w Bazylei. Po roku 1437 Kanty zajął się prawdopodobnie rękopisami soborowymi (BJ 414, 2370), do których materiał dostarezyć mógł po swym powrocie właśnie Mikołaj z Kozłowa lub inni delegaci polscy w Bazylei. Treściowo kodeks ten uzupełnia rękopis 2372 i Vat. Lat. 14 182. Że rks 2369 został oprawiony po r. 1439 , o tym świadezą dwa dokumenty bazylejskie z r. 1436 (f. 1-5) i 1439 (f. 143 sq), przepisane obcą ręką.

94 Wymienione folia zawierają tekst anonimowej Exhortatio b. Hieronimi, przepisany tak kaligraficznie, że budzi się wątpliwość czy mamy tu do czynienia $\mathrm{z}$ autografem Świętego, który, jak wiemy, nie posiadał pięknego charakteru pisma. Por. przypis 85 .

$9_{5}$ Klocek rękopiśmienny. Pozostałe karty są obcymi autografami, ale kilka z nich zostało jeszcze zapisanych przez Kantego bez oznaczenia daty. Por. R. M. Zawadzki, Lektura.

96 Pierwsza składka w rękopisie oznaczona jest kustoszem 11, co każe nam przypuszczać, że jednak istniał zaginiony dziś rękopis, zawierający komentarz do I księgi Analitica Priora Arystotelesa.

97 Datację przyjmuję za M. Markowskim (por. przypis 74). Rks został jednak oprawiony znowu po r. 1439, gdyż jako karty ochronnej użyto kopię dokumentu Władysława Warneńczyka z 11 XII 1439.

${ }_{98} \mathrm{~W}$ obu rękopisach brak datacji. Kryterium chronologiczne ustaliłem w przypisie 93.

99 Por. przypis 94 i 100 .

$100 \mathrm{Z}$ kolofonu na f. $86 \mathrm{r}$ wynika, że kopista ukończył przepisywanie traktatu św. Augustyna De doctrina christiana we wtorek $8 \mathrm{X}, \mathrm{tj}$. w wigilię św. Damazego. Taki układ dat występuje w r. 1420, 1426, 1437, 1443, 1448 itd. Odrzuciwszy lata skrajne opowiadam się za r. 1443 tylko na podstawie różnic formalnych, przede wszystkim pisma. Jest ono niepodobne do żadnego $\mathrm{w}$ tym samym rękopisie. Poza tym data 1443 bliższa jest dacie 1441, która jest zupełnie pewna. Jedno jest niewątpliwe, że rks BJ 2724 został oprawiony po 6 VII 1441. 


\begin{tabular}{|c|c|c|}
\hline 446 & $5 / 7 \mathrm{~V}-7 \mathrm{X}:$ & (2) Vat. Lat. 14643101 \\
\hline & $(30$ VI ?) - 1448, 3 III: & Vat. Lat. 14638102 \\
\hline ? & 14/19 VI - 1451 ?, $17 \mathrm{VI}:$ & (I) Vat. Lat. $14641^{103}$ \\
\hline & $\begin{array}{c}7 / 10 \mathrm{I}-17 \mathrm{~V}: \\
2 \mathrm{VI}-7 \mathrm{VII}:\end{array}$ & $\begin{array}{l}\text { BJ 1690, f. } 1-237104 \\
\text { Vat. Lat. } 14645 \text {, f. } 1-5\end{array}$ \\
\hline & $\begin{array}{l}\text { (post 25/28 II): } \\
12 / 16 \text { III }-20 / 24 \text { III: }\end{array}$ & $\begin{array}{r}\text { BJ 1690, f. } 255-290 \\
\text { f. } 243-254\end{array}$ \\
\hline & $\begin{array}{l}\text { ante } 5 / 10 \text { VII }-30 \text { VIII: } \\
\text { ante } 24 / 27 \mathrm{X}-9 \mathrm{XII}:\end{array}$ & $\begin{array}{r}\text { Vat. Lat. } 14645, \text { f. } 145- \\
\text { f. } 56-\end{array}$ \\
\hline & $?-10 \mathrm{XI}:$ & BJ 1216, f. $1-112$ \\
\hline & $\begin{array}{l}\text { 1/4 IV }-30 \text { VIII: } \\
\text { (post } 30 \text { VIII): }\end{array}$ & $\begin{array}{l}\text { f. } 113-270^{105} \\
\text { f. } 271-291106\end{array}$ \\
\hline & $16 \mathrm{XI}-1457 ?, 25 \mathrm{IV}:$ & (II) Vat. Lat. 14644107 \\
\hline & $2 / 3 \mathrm{~V}-5 \mathrm{IX}:$ & BJ 1691 \\
\hline & $(3 \mathrm{XII})-$ & BJ 2371; \\
\hline
\end{tabular}

101 Rks (1) i (2) dają kompletny tekst postyllii Holcota Super sapientian Salomonis. Cezura tekstu występuje w lekcji 104.

102 Data rozpoczęcia kopii (f. 1r) niezbyt czytelna. Rok 1447 nie występuje, ale jest tak oczywisty, że daję go bez pytajnika. Pełna data zakończenia w kolofonie (f. 293).

103 Por. przypis 109.

104 Rękopis ten wraz z następnym (Vat. Lat. 14 645) jest typowym przykładem chronologicznego pomieszania składek, które musiały powstawać sukcesywnie W luźnych poszytach, gromadzonych w jakimś miejscu przez 3 lata nim po r. 1454 zostały oddane do introligatora. Ten zapewne dokonał podziału na dwa kodeksy, nie troszcząc się o właściwą kolejność składek. Rękopis BJ 1690 jest również ciekawy przez to, że na jego podstawie możemy z całą dokładnością powiedzieć w jakim tempie Kanty przepisywał poszczególne składki, ponieważ na początku każdego seksterionu umieścił datę dzienną według cisiojanusa.

$105 \mathrm{Na}$ podstawie kolofonów z tego rękopisu ustala się datę urodzenia Jana Kantego na dzień 24 VI 1390 (por. J. Swastek, 178 nn). Nie zwrócono jednak uwagi, że w kolofonie na k. $145 \mathrm{r}$ mamy znowu pomyłkę w roku (por. przypis 89). Czytamy bowiem, że Regula Pastoralis papierza Grzegorza została ukończona przez Jana Kantego w czwartek po św. Tyburcjuszu i Walerianie w r. 1457. Taka data dzienna jest trafna tylko dla r. 1456, gdyż w roku następnym święto tych męczenników wypadało w sam czwartek. Że istotnie chodzi tu o rok 1456, świadczy o tym nota historyczna następująca po wspomnianym kolofonie. Dowiadujemy się z niej, że eodem anno 1456 urodził sie (1 III) i został ochrzczony (11 IV) królewicz Władysław, syn Kazimierza Jagiellończyka. Otóż Kanty widocznie zorientował sie w pomyłce bo końcowa szóstka w tej notatce jest zapisana na razurze. Nie ma zaś mowy o tym, żeby poszczególne części tego zakończenia traktatu Grzegorza W. mogły być napisane przez kopistę w różnym czasie. Kolor atramentu, grubość pióra i jednakowa kaligrafia tekstu na tej i następnych stronach dowodnie świadczą o jednoczesności zapisu tego miejsca. Już bowiem verso tej karty ma pewną datę 1456 .

${ }_{106} \mathrm{Te}$ ostatnie karty w rękopisie BJ 1216 nie mają żađinej datacji określonej przez kopistę. Ponieważ są integralnie złączone $\mathrm{z}$ poprzedzającą częścią tegoż kodeksu (kustosze), a rękopis jest uporządkowany chronologicznie, więc też przypuszczam, że i ta ostatnia składka została przepisana gdzieś we wrześniu $1456 \mathrm{r}$. 107 Por. przypis 109.

108 Trzy ostatnie rękopisy BJ $(1691,2371,2206)$ zawierają dwie pierwsze części Summy Teologicznej Tomasza z Aquinu. Kompletną datację posiada tylko rks 1691. Zakładając, że następne części Summy zostały skopiowane we właściwej kolejnośc1, 
$1461,22 \mathrm{~V}-30 \mathrm{IX}:$

1462 ?, 1/4 VIII - 1463 ?, 17 I:
(III) Vat. Lat. $14646{ }^{109}$

(IV) Vat. Lat. 14648

Z powyższego zestawienia wynika, że obecny zbiór rękopisów Jana Kantego powstał dokładnie w ciągu 40 lat pracy, o ile moje przypuszczenia co do rękopisów nie datowanych są trafne. Gdybyśmy w tym miejscu raz jeszcze postawili pytanie, czy ta kolekcja nie była przypadkiem obszerniejsza, to musimy na nie odpowiedzieć twierdząco. Prawie na pewno istniał jeszcze jeden zbiór kazań, sporządzony bez wątpienia w latach 30-tych, prawie na pewno była I księga komentarza do Analityk Pierwszych Arystotelesa, napisana w pierwszej połowie roku 1435. Czy były jeszcze jakieś inne manuskrypty Jana Kantego? Jeśli tak, to może dwa lub trzy najwyżej i to formatu in $4^{\circ}$. Przyjmuję bowiem, że kopista nie był w stanie przepisać więcej jak jakieś 300 kart rocznie. Należy bowiem wiedzieć, że jego praca nie kończyła się na zwykłym skopiowaniu takiej czy innej ilości tekstów. Kanty nie tylko kolacjonował później swój rękopis i nanosił na jego marginesy dłuższe lub krótsze notatki, glossy itp., ale po latach nieraz wracał do skopiowanych traktatów. Wiadomości te nie są już tylko przypuszczeniem, domysłem. Znajduję ich źródło właśnie w takich marginalnych notatkach, których pełno w Janowych rękopisach.

\section{WYKAZ TREŚCI RĘKOPISOW JANA KANTEGO}

$\mathrm{Na}$ koniec naszych rozważań daję przegląd treści omawianych manuskryptów. Nie jest możliwe sporządzenie zestawienia całkowicie kompletnego z przyczyn natury formalnej ${ }^{110}$. Uznałem, że dla naszych potrzeb

tym samym uzyskujemy proponowaną przeze mnie datację. Data 3 XII jest na k. $174 \mathrm{r}$ rksu 2371, data 2/4 VIII w kolofonie (k. 270v) rksu 2206.

109 Oznaczone przeze mnie cyframi rzymskimi (I-IV) rękopisy to kopia czterech części Komentarza do św. Mateusza. Jak wykazal M. Rechowicz, autorem dzieła był nauczyciel Jana Kantego, znany teolog krakowski Benedykt Hesse $(\dagger 1456)$. Hesse pisal swe dzieło w latach 1441-1449. Ustalenie zaś daty, kiedy Jan Kanty rozpoczął kopiowanie tego traktatu, nastręcza duże trudności. Datowany kolofon mamy tylko przy końcu części III (Vat. Lat. 14 646; por. J. Swastek, 202). Co prawda na początku części II po dacie dziennej określonej sylabami cisiojanusa dopisał kopista rok 1456, ale grafia tej lekcji budzi wątpliwości czy mamy tu do czynienia z jednoczesnością zapisu dnia i roku. Nie jest wykluczona późniejsza interpolacja dokonana jednak ręką Jana Kantego. Jeśli jednak przyjmiemy, że Kanty przepisywał poszczególne tomy Komentarza zgodnie z ich merytorycznym porządkiem, to nie można znaleźć innych terminów dla kopii sporządzonej przez Kantego jak te, które powyżej proponujemy. Wobec tego należałoby poszukać teraz odpowiedzi, co było powodem, tych znacznych przerw między kopiami poszczególnych tomów. Definitywne rozstrzygnięcie tej kwestii nie jest na razie możliwe.

110 Szczegółowo rękopis może być opisany tylko z autopsji. Ten warunek właśnie spełniają rękopisy Jana Kantego w BJ (por. przypis 75-76). Trzeba będzie jednak długo poczekać nim uda się wziąć do ręki jego autografy, przechowywane w zbiorach BV. 
wystarczy podać tylko teksty dłuższe czy to anonimowe, czy też wiadomego autora. Od tej zasady odstąpiłem w dwóch wypadkach. Nie wyszczególniam autorów (jeśli są znami) ani samych kazań. Tych tekstów jest kilkaset (!). Są to przeważnie kazania Jakuba de Voragine i osób współczesnych Kantemu. Do tej grupy kodeksów wliczyłem też te, które zawierają przemówienia, traktaty czy kazania z czasów soboru w Konstancji i w Bazylei. Nie rozstrzygam natomiast dylematu czy wyliczone przeze mnie pod imieniem Jana z Kęt teksty są jego oryginalnymi pracami, naturalnie w tym sensie, w jakim rozumie się oryginalność autorów (nie tylko polskich) z w. XV. Pominąłem więc tylko dużą ilość luźnych notatek i marginaliów. Tych bowiem nie sposób ująć w jakąś merytoryczną całość. Nazwiska autorów i tytuły podaję według dzisiejszej nomenklatury ${ }^{111}$. Jeśli Jan Kanty przypisał dany traktat innemu autorowi (najczęściej chodzi tu o pseudoaugustyniana), to lekcję Janową umieszczam w nawiasie okrągłym. W tyłułach, zwłaszcza traktatów anonimowych, stosuję cudzysłów tylko wtedy, gdy zatrzymuję inskrypcję podaną przez kopistę.

\section{a. Auctores:}

ADAMUS de Sancto Victore, Sequentia de Sancta Trinitate: BJ 1691, f. 245 .

ALCHERUS Clarevalensis (Augustinus), De spiritu et anima (fr. c. $34-$ —35) : BJ 2375, f. 255 sq.; Soliloquium : f. 159r - 183v.

AMBROSIUS Autpertus (Augustinus), De conflictu vitiorum: BJ 2375, f. $78-86$.

AMBROSIUS, Exameron: BJ 1216, f. 223-270.

AUGUSTINUS, De adulterinis coniugiis : BJ 2724, f. 230-266.

De agone christiano: BJ 2724, f. 177-194.

De doctrina christiana: BJ 2724, f. 1-86; BJ 2375 (excerpta), f. $184-209^{112}$.

De dono perseverantiae: BJ 2603, f. $23 \mathrm{v}-52$.

Enchiridion : BJ 2375, f. 5-37.

111 Za podstawę przyjąłem tę nomenklaturę, jaką stosuje Patrologia Latina. Incipity notuję $w$ zasadzie tylko w wypadku, jeśli dany tekst nie został dotąd wydany drukiem.

$112 \mathrm{Na}$ k. 184-252 Jan Kanty przepisał jakieś „V libri b. Augustini de doctrina christiana”. Jednakże przy ponownej lekturze tego traktatu stwierdził, że ,hic liber est in toto corruptus" (k. 184r), czego dowiódł, znacząc na marginesie tytuły poszczególnych tekstów, jakie złożyły się na ten rzekomy traktat św. Augustyna, a mianowicie: fragmenty ks. I-III De doctrina christiana, Sermo 214 Augustyna, anonimowe kazanie (k. 214-217: Cum vidisset Ihesus turbas ... Si queritur, quid significet mons ...), Expositio Dominicae Orationis, fragment z Lactantiusza i wreszcie jakiś tekst de peccatis. Ponadto od k. 209 usiłował zamazać żywą paginę z oznaczeniem IV i V księgi rzekomego dzieła św. Augustyna. Por. przypis 113. 
Epistula CCXXX ad Probam : Vat. Lat. 14 643, f. 263-267.

Contra Faustum Manichaeum libri XXXIII : BJ 1216, f. 1-112;

BJ 2369 (excerpta), f. $144 \mathrm{v}, 300-307$.

De gratia et libero arbitrio : BJ 2603, f. 53-74.

De praedestinatione sanctorum : BJ 2603, f. 1-23.

Regula ad servos Dei : BJ 2372, f. 1-5.

Retractationum libri II : Vat. Lat. 14 645, f. 57-76r.

Soliloquiorum libri II : BJ 2724, f. 194-230r.

Sermones ad eremitas monachos: Vat. Lat. 14 645, f. 145-162.

Sermones XII : Vat. Lat. 14645 , f. $162 \mathrm{~V}-170$.

Sermo de disciplina christiana : BJ 2375, f. $89 \mathrm{v}-93 \mathrm{v}{ }^{113}$.

Sermo de decem chordis: BJ 2724, f. 109-116.

Sermo CCXIV „Expositio symboli”, BJ 2375, f. 209v-214r ${ }^{114}$.

ps-(Augustinus), „Augustinus a se ipso ad se ipsum".

- Quid interest inter Deum et Dominum. Respondeo hoc interest, ut in Dei appellatione Patrem in domini Filium intelligimus...: BJ 325, f. 121v-127115.

„Libellus b. Augustini de contemptu mundi ad clericos”.

- Audite, fratres carissimi, salutiferam Patris doctrinam ... : BJ 2375, f. 119-122 r.

„,Sermo Chrysostomi de Spiritu Sancto”.

- Hodie nobis terra facta est... : BJ 2724, f. 132-137r. ${ }^{116}$

„De vera et falsa poenitentia”.

- Quantum sit appetenda gratia poenitentiae ... BJ 2724, f. $137 \mathrm{v}-157 \mathrm{r}$.

„De visitatione infirmorum”.

- Visitationis gratia nepoti meo carissimo ... BJ 2724, f. $116 \mathrm{v}-127 \mathrm{v}$. ${ }^{117}$

„Liber b. Augustini de vita christiana”.

- Ego Augustinus primus peccator ... : BJ 2375, f. 55v-65.

cf. ALCHERUS, AMBROSIUS Autpertus, EUSEBIUS, FULGENTIUS, GENNADIUS, HUGO, IOANNES Fiscamensis, VALERIANUS; Libellus florigerus, „De diversis..."

113 Tu powtarza się ta sama historia co przy tekście Augustyna De doctrina christiana (por. przypis 112). Na k. $89 \mathrm{v}-100 \mathrm{r}$ przepisał Kanty trzy księgi innego traktatu św. Augustyna - De domo disciplinae. Miał jednak potem wątpliwości co do autentyczności całego tekstu. Okazało się to słuszne przy dokładnym jego przestudiowaniu. W rezultacie zupełnie dokładnie wydzielił z niego cztery rozdziały z III księgi Sentencji Izydora z Sevilli. Nie potrafił jednak znaleźć źródła tekstu Vanos eventus..., czego i nam się zresztą nie udało. Być może ilość notatek marginalnych była znacznie większa ale bardzo zbutwiałe marginesy górne, a zwłaszcza dolne, wykruszyły się we wielu miejscach.

114 Por. przypis 112.

115 Por. R. M. Zawadzki, Lektura, 411 n.

116 W podanym tytule podkropkowany został, a więc wykreślony przez kopistę wyraz "Chrysostomi”. Na dolnym zaś marginesie tejże strony Kanty dopisał: Hic liber alias intitulatur Augustini de firmitate Ecclesiae et missione Spiritus Sancti. Ta uwaga musiała być dopisana w zupełnie innym czasie niż kopia traktatu, o czym świadczą różnice w kolorze atramentu i rodzaju pióra.

117 Nad tytułem dopisek ręką Jana Kantego, ale w zupełnie innym czasie naniesiony: Non inveni inter titulos. 
BALBUS Ioannes, Catholicon (excerpta) : Vat. Lat. 14642 , f. $7 \mathrm{v}-8,17-$ 20, 286-295, II sq.

BASILIUS cf. Textus anonymi (,Tractatus...")

BARTHOLOMEUS de Sacro Concordio, Summa de casibus conscientiae (excerpta) : BJ 2603, f. $237 \mathrm{r}$... 267r.

BERNARDUS Clarevalensis, De consideratione libri V : BJ 1216, f. 145v-166r.

Epistulae 52, 14, 84(fr.), 71(fr.), 57(fr.), 60(fr.), 17, 58, 125, 22; BJ f. $179 \mathrm{v}-180 \mathrm{r}$.

Epistula CCXXXVIII ad Eugenium papam: BJ 1216, f. 179.

Epistula CCXLIII ad Romanos: BJ 1216, f. 180-181r.

De gradibus humilitatis et superbiae: BJ 1216, f. 166-176r.

Homiliae IV super „Missus est”: Vat. Lat. 14645 , f. 170-179r.

Sermo XXVI de obitu fratris Girardi : BJ 1216, f. 271-273r.

Sermones super Canticis (excerpta): BJ 1216, f. 273-279.

ps-(Bernardus), Scala claustralium : BJ 1216, f. 176v-178.

DAMASCENUS Ioannes, De fide orthodoxa: Vat. Lat. 14645 , f. $1-55$.

EUCHERIUS Lugdunensis (Hieronimus), Formulae spiritualis intelligentiae: BJ 2375, f. $74 \mathrm{v}-77$.

EUSEBIUS Gallicanus (Augustinus), Sermo XXIII de beato latrone: BJ 2724, f. $127 \mathrm{v}-131$.

FLAVIUS Iosephus, De bello iudaico (fr. libri VI-VII) : 2724, f. 279-290. FULGENTIUS de Ruspe (Augustinus), De fide ad Petrum:BJ 2375, f. $38-55 \mathrm{r}$.

? GENNADIUS Massiliensis (Augustinus), De ecclesiasticis dogmatibus BJ 2724 , f. $86 \mathrm{v}-93$.

GREGORIUS I, Homiliarum libri II : Vat. Lat. 14645 , f. $76 \mathrm{v}-142 \mathrm{v}$.

Homiliae super Ezechielem: Vat. Lat. 14 645, f. 179-259.

Regula pastoralis: BJ 1216, f. 113-145r.

? GUALTERUS de Brugis, (Excerpta) IV libri Sententiarum: BJ 2372, f. $158 \mathrm{v}-160$.

GUILLELMUS Altissiodorensis, Summa aurea in IV libros Sententiarum (excerpta) : BJ 2603, f. 257v-264v.

HENRICUS de Hassia, ,Super prologum Bibliae”.

- Quattuor sunt, in quibus exercet vita humana iustorum ... : Vat. Lat. 14646 , f. $1,250 \mathrm{v}$.

HESSE Benedictus, Commentarius in Evangelium Matthaei: Vat. Lat. $14641,14644,14646,14648$.

HIERONIMUS, Contra Vigilantium (fr. cap. 14-16): BJ 2372, f. 161. 
Epistulae 52, 14, 84(fr.), 71(fr.), 57(fr.), 60(fr.), 17, 58, 125, 22; BJ 2372 , f. $161 \mathrm{v}-211$.

ps-(Hieronimus), „De virgine Maria”.

- Didicit Dei genitrix hebraicas litteras ...: BJ 2372, f. 61-63r.

cf. EUCHERIUS; „Exhortatio b. Hieronimi”.

HOLCOT Robertus, Postilla super sapientiam Salomonis: BJ 1375; Vat. Lat. 14643 , f. $5 \mathrm{v}-262$.

HUGO de St. Victore, Expositio in regulam b. Augustini: BJ 2372, f. $6-41$.

HUS Ioannes, ,Gesta Christi” : Vat. Lat. 14 642, f. 1.

ps-(Ignatius) Antiochensis, Epistulae IV : Vat. Lat. 14643 , f. 1v-2r.

IOANNES Duns Scotus, Registrum quaestionum quodlibeti „Utrum in divinis" : BJ 2206, f. 155.

IOANNIS Fiscamensis, „Suspiria b. Augustini” seu Libellus de scripturis et verbis Patrum collectus : BJ 2724, f. 93v-109.

IOANNES de Kęty, Commentum super Analitica Priora Aristotelis liber II.

- Non propter hoc autem accidere falsum, quod saepe in disputationibus sit ... : BJ 2078, f. 1-27, 131-133 ${ }^{118}$.

Commentum super II libros Analiticorum Posteriorum.

- Omnis doctrina et omnis disciplina ex praeexistenti fit cognitione intellective: BJ 2078, f. 28-130.

Disputata super VIII libros Phisicorum Aristotelis.

- Circa primum Phisicorum queritur utrum diffinitio philosophiae posita II $^{\circ}$ Metaphisicae sit bona ... : BJ 2376. ${ }^{119}$

Glossa marginalis et interlinearis in Novum Testamentum : Vat. Lat. 14642 , f. $21 \ldots 249120$.

Epilogus in librum Iob.

- Fuerunt ergo omnes anni vitae eius ducenti XLVIII ... : BJ 325, f. 58v$-59 \mathrm{r}^{121}$.

Index CXLIX peccatorum.

- Nota peccata cordis: cogitatio, delectatio, consensus ... : BJ 325, f. 142v$-143 \mathrm{r}$.

IOANNES de Štékna, Carcer animae (excerpta) : BJ 2369, f. 165-167; BJ 2377, f. 99v ... 308v.

118 Oba komentarze do Analityk Arystotelesa omawia M. Markowski (Burydanizm..., jw., s. 305). Por. przypis 96.

119 Por. M. Markowski, jw., 377. Por. przypis 97.

120 Trudno powiedzieć czy wszystkie marginalia wyszły tutaj spod ręki Jana Kantego. Na pewno ciągłą glossę do Apokalipsy przepisał jej kopista, tzn. Jan z Warty. Znajdujemy tu również dopiski poczynione jeszcze innymi rękami z w. XV. Por. przypis 86.

121 O epilogu do księgi Hioba, jak i o spisie grzechów - por. R. M. Zawadzki, Lektura, 409, $412 \mathrm{n}$. 
ISIDORUS, Sententiarum seu De summo bono libri III : BJ 1216, f. 181v-222; BJ 2375 (fr. III 48-51), f. 96v-98 122.

LACTANTIUS, Divinarum institutionum liber VI (De vero cultu): BJ 2375, f. $221-251^{123}$.

LUDOLPHUS de Saxonia, Vita Christi (fr. c. 66-87) : BJ 2369, f. 13-36, 202 sqq.; BJ 2372 (fr. c. 40), f. 69.

MARCHESINUS Ioannes, Mammotrectus super Bibliam: Vat. Lit. 14 647, f. $1-126,130-197$.

PIUS II, Dialogus contra Bohemos et Taboritas : Vat. Lat. 14 644, f. 222$-228$.

Petrus Damiani cf. Textus anonymi (,Tractatus...”)

PETRUS de Tarantasia, Sententiarum I-II excerpta : BJ 2206, f. 155v$-156 \mathrm{v}, 270 \mathrm{v}-272$; BJ 2603; f. 74v-96r, 133-169.

THOMAS de Aquino, Quaestiones de veritate: Vat. Lat. 14 638, f. $1-295$. Quodlibetorum I-VI, VIII-XII quaestiones selectae: BJ 2372, f. $105-130$.

Sententiarum I-IV excerpta: BJ 325, f. 1, 155v, 195-197 124; BJ 2371 , f. $174-180$; BJ 2377 , f. $70 \mathrm{v}-73 \mathrm{r}$; Vat. Lat. 14648 , f. $1-2$, $210-211$.

Summa contra gentiles: BJ 1690.

Summa Theologiae I-II : BJ 1691, 2371, 2206.

Summae Theologiae fragmenta: BJ 1375, f. 250; BJ 2724, f. 302.

Excerpta ex variis operibus : BJ 2603, f. $96 \ldots 266$.

THOMAS de Argentina, Registrum quaestionum I-IV Sententiarum : BJ 2206, f. 252-254; Vat. Lat. 14646 (fr. IV 22), f. 253v-254r, 255r.

VALERIANUS Cameliensis (Augustinus), Homilia I de bono disciplinae: BJ 2375, f. 93-96 ${ }^{125}$.

b. Collectiones:

BIBLIA, Liber Esdrae I-III, Tobiae, Iudith, Esther, Iob, Proverbiorum, Ecclesiastes, Cantici Canticorum, Sapientiae, Ecclesiastici : BJ 325, f. $3-112$ r. ${ }^{126}$

Evangelium Nicodemi : BJ 2724, f. 291-301.

SERMONES : BJ 2369, 2372, 2377; Vat. Lat. 14 182; BJ 1216, f. 289v—291;

BJ 2375, f. 214-217r, 253-255r; BJ 2724, f. 302; Vat. Lat. 14647 , f. $128 \mathrm{sq}, 197 \mathrm{v}-199$.

122 Por. przypis 113.

123 Por. przypis 112.

124 Por. R. M. Zawadzki, Lektura, 413 n.

125 Por. przypis 113.

126 Por. R. M. Zawadzki, Lektura, 407-409. 
ACTA CONCILII CONSTANTIENSIS ET BASILIENSIS: BJ 414; BJ 1690, f. $243-290$; BJ 2370.

c. Textus anonymi:

„Arenga ad suscipiendum legatum solemnem".

- Pro honore ac debita susceptione huius magnifici et praestantissimi viri de mandato domini regis ... : BJ 2372, f. 212.

- Quamquam homines regiae stirpis pro populo christiano multa reddant... : BJ 2603, f. $270 \mathrm{v}-271 \mathrm{r}$.

De baptisatione.

- Sicut sunt septem dona Sancti Spiritus, ita septem sunt baptismatis secundum Albertum. Primum sal benedictum ... : BJ 2375, f. 1V-4.

De candelis portandis et de sacerdote.

- Triplex ratio quare candelae portantur. Primo propter removenaiam erroneam consuetudinem ... : BJ 2377, f. 22.

„De choreis".

- Choreae sunt processiones diaboli ... : BJ 2603, f. 271v-273v.

- Chorea est circulus, cuius centrum est diabolus ... : Vat. Lat. 14647 ,

f. $126 \mathrm{v}-127$.

„De conscientia”.

- Iudicium rationis est multiplex, conscientia multiplicata ... : BJ 2603,

f. $267 \mathrm{v}-268 \mathrm{r}$.

De contemplatione.

- Contemplatio tribus impeditur in hac vita. Primum est pecatorum infectio ... : Vat. Lat. 14643 , f. 2.

„Chronica”.

- Tiberius imperavit annis 18 usque ad terminum, quo passus est dominus Ihesus ... : BJ 2603, f. 269-270r.

Decretorum de casibus excommunicationum et de interdictis excerpta.

- Casus excommunicationum, quorum absolutio ad solum papam pertinent. Primus de eo, qui verberat clericum ... : BJ 2377, f. 76-91r.

„Descriptio Christi”.

- Legitur in annalibus librorum Romanorum, quod Dominus noster ... : BJ 2372 , f. 61.

Discordantiae quaestionum Summae Theologiae et Sententiarum Thomae de Aquino.

- Primum est, quod in primo Sententiarum di. 1 ar. 4 dicit, quod Deus non est subiectum ... : BJ 1691, f. $243 \mathrm{v}-245$.

„Divisio Bibliae".

- Secundum 〈Augustinum〉 primo libro super gentes ad litteram capitulo primo Sacra Scriptura canonis habet duas principales partes.... : BJ 325, f. $152-159 \mathrm{r}^{127}$.

127 Por. tamże, 413. 
,Expositio Dominicae Orationis”.

- Orantes autem, Dominus ait, nolite multiloqui esse sicut ethnici...: BJ 2375 , f. $217-220^{128}$;

- Caput nostrum Ihesus nos filios suos intendit informare...: BJ 2370, f. $164-167$.

De Eucharistia.

- Quattuor genera hominum excludantur ab esu agni paschalis ... : BJ 2377, f. $132-133 \mathrm{v}$.

„Exhortatio beati Hieronimi”.

- Dum(?) gloriosissimum athletam Christi beatissimum Hieronimum ... : BJ 2724, f. $267 \mathrm{r}-278^{129}$.

Libellus florigerus seu ,Flores b. Augustini”.

- Quorundam librorum gloriosi ... Da mihi Domine scire ... : BJ 2375, f. $101-$ $-118$.

„,De diversis b. Augustini libris collecta”.

- Ob carentiam librorum b. Augustini ... Abel natus est post Cayn ... : BJ 2375, f. $122 \mathrm{v}-158$.

„,De gradibus virtutum”.

— Primo autem notandum de gradibus caritatis... : BJ 2375, f. 66-74r.

De miraculo monachi cisterciensis in monasterio Waltensi.

- Sicut legitur de quodam monacho cisterciensis ordinis monasterii Waltensis habuit enim ille sacerdos singularem gratiam a Deo ... : Vat. Lat. 14648 , f. $1 \mathrm{v}$.

„De notionibus proprietatis personarum in divinis et relationibus differentiae cum declaratione".

- Notandum secundum Boetium in libro de Trinitate relatio in divinis multiplicat Trinitatem ... : BJ 1691, 245v-246.

„Oratio Salomonis”.

- Et inclinavit Salomon genua sua in conspectu totius populi... BJ 325, f. $112 \mathrm{r}^{130}$.

Quaestiones quaedam.

- Cur Deus dederit dampnando tam nobilia naturalia ...;

- Et si quaeris propter quid istum mundum creavit Deus...; BJ 2372, f. $153-158$.

„De poenitentia”.

- Nota de poenitentia quantum ad satisfactionem et sunt sex praecipue necessaria. Primo requiritur ad satisfactionem abstinentiae ... : Vat. Lat. 14647 , f. 200 .

„Septem species eleemosinae”.

- Prima, quam sibi insi homo dat, ut quando pro se ipso orat... : BJ 2372,

f. $66 \mathrm{r}$.

„De quinque panibus ordaceis".

128 Por. przypis 112

129 O ile ten tekst przepisał Jan Kanty - por. przypis 94.

130 Por. R. M. Zawadzki, Lektura, 409 n. 
- Nota, quilibet homo, qui ambulat in solitudine huius mundi debet habere quinque panes ordaceos ...: BJ 2372, f. 66v.

„Excerpta de Talmuth et disceptationes christiani cum iudeis et obiectiones cum solutionibus".

- Talmuth est doctrina iudeorum et dividitur in IV libros ... : BJ 2372, f. $42-60$.

„Tractatus de laude monasticae vitae Basilii vel Petri Damiani”.

- Libet de monasticae vitae meritis pauca perstringere ... : BJ 2372, f. 229v-232 .

„,De tribus, per quae impletur omne peccatum”.

- Tria sunt, quibus impletur omne peccatum: suggestione, delectatione, consensione ... : BJ 2375, f. $251-252 \mathrm{v}^{131}$.

„De tribus substantialibus ad religionem pertinentibus”.

- Affectu filiali, quo constringor ... : BJ 1216, f. 281-289.

„Utilia et praeparatoria volenti ad communicationem sacram accedere”. - Nota, quod sicut ad istum panem, de quo conficitur corpus(?) Christi requiruntur VII ... : BJ 2372, f. 64-65.

Fragmentum textus.

- Vanos eventus huius saeculi saepius considerare debemus ... : BJ 2375,

f. $99 \mathrm{v}-100^{132}$.

Żywię nadzieję, że zebrany $\mathrm{w}$ tej rozprawie materiał przyczyni się do znacznego postępu w zakresie prac omawiających życie i działalność skrypturystyczną św. Jana z Kęt. Nie muszę dodawać, jak wiele kryje się tu problemów i zagadnień trudnych, zawiłych, może nawet nierozwiązalnych. Można postawić sobie pytanie, czy warto przeprowadzać aż tak skomplikowane poszukiwania, by dotrzeć do źródeł biografii mistrza z Kęt, by odkryć możliwie najwięcej faktów z jego bogobojnego i pracowitego życia? Trudno oczywiście przewidzieć w jakim stosunku pozostanie nasz trud badawczy do osiągniętych rezultatów. Myślę jednak, że będzie on opłacalny w każdym wypadku, jeśli tylko nawet drobny szczegół z jego życia uda się nam wyjaśnić lub sprostować, a tym samym przybliżý dzisiejszemu pokoleniu tę niezwykłą osobowość w naszej kulturze duchowej i intelektualnej.

W rocznicowym roku 1973 składamy hołd dwom jakże różnym, a jednocześnie tak bardzo sobie bliskim postaciom, jakimi byli św. Jan $\mathrm{K}$ a n ty i młodszy odeń astronom Mikołaj K o pe r n i k. Nie byli braćmi $\mathrm{w}$ geniuszu, a przecież jednak obaj wpatrzeni w niebo zdążali, każdy na swój sposób, ku temu samemu celowi - ku Praw dzie. 


\section{A R G U M E N T U M}

\section{DE STUDIIS AD VITAM ET MANUSCRIPTA S. IOANNIS DE KĘTY PERTINENTIBUS}

Omnium litterarum, quae de s. Ioannis Cantii vita et immortali cultu narrant, tres in partes collocari possit dispositio. Sunt enim (1) de Cantio brevisimae adnotationes per diversa praecipue opera historica nec non poemata dispersae, item (2) compendia vitae, virtutum, miraculorum illius Sancti scriptis, quae acta sanctorum continent, inserta, demum (3) libri de solo Ioanne Cantio singulares conscripti et separatim in lucem editi.

S. I o a n nes de Kęty, patronus inclitae Poloniae atque Almae Matris Jagellonicae illustre ornamentum, anni 1473 vigilia Nativitatis Iesu Christi obdormivisse in Domino traditur et in ecclesia academica s. Annae Cracoviae sepultus esse.

Primus, ut videtur, Ioannes Dlugosz, canonicus Cracoviensis, tum illustrissimus Poloniae historicus (1415-1480), mentionem de Ioanne Cantio, magistro artium et professorae s. theologiae in huiusce urbis celeberrima Universitate, in Libro Beneficiorum Dioecesis Cracoviensis fecit, nam prodigia et miracula plurima per gratam illius Sancti intercessionem eodem iam tempore patrata erant. Inter codices antiquos Bibliothecae Jagellonicae autographum habemus Matthiae de Kościan, tunc praepositi s. Annae, qui illa miracula inde ab anno 1475 ipse conscripserat et postea alli ibidem praepositi testimonia de similibus miraculis relata eodem codici (BJ 105) annexerunt. Fama miraculorum Ioannis Cantii usque ad Hartmanum Schedelium pervenit, qui in suo Libro Chronicorum de eodem Servo Dei perpauca verba protulit. Exstat quoque Vita Servi Dei Ioannis Cantii versu heroico descripta, incipiens verbis "Carmine ne sileas”, cuius auctor ignotus nobis est. Eodem tempore Nicolaus Tauchen de Nissa Silesiorum epitaphium defuncti Ioannis Cantii composuit. Sunt quidem alia plura testimonia auctorum saeculo XVI et XVII vigentium, quae in Cracoviensis Canonizationis B. Ioannis Cantii [...] Summario (1675 et 1730 Romae) collecta, ad vitam tamen nostri Patroni cognoscendam parum videntur apta.

Ad alteram partem litterarum de vita, virtutibus miraculisque magistri de Kęty compendia eius vitae similesque enarrationes pertinent. Quorum praestantissimum est sextum capitulum libri IV Chronicae Polonorum Matthiae de Miechów (1520) et descriptio vitae Ioannis Cantii a Petro Skarga in praeclaro opere lingua polonica scripto (Vitae Sanctorum Veteris et Novi Testamenti, Cracoviae 1610) facta. Multum quoque valent, quae a Friderico Schembek SJ provinciae Polonae, de vita Ioannis Cantii scripta erant et ad H. Rosveyum in Belgiam missa (1603), nunc in Actis Sanctorum-Octobris VIII (p. 1047 sq.) legi possunt. Nam F. Schembek unus ex omnibus Cantii biographis nomen patris eius - Stanislaum Vacengam - indicat fuisse. Nescimus fontem historicum huius nominis nullo alio documento testificati, id quod same dolendum. Imago vitae Ioannis de Kęty, scriptis Matthiae de Miechów, P. Skargae, F. Schembek contenta sancitaque, exemplum aptum et fons certus hagiographis posterioribus profuit.

Singularem librum vitae miraculisque Ioannis de Kęty consecratum Adamus Opatovius in lucem bis edidit Cracoviae lingua latina (1628) et polonica (1632) scriptum. Aliae, ut dicuntur, biographiae tempore canonizationis illius Servi Dei typis vulgatae sunt (1767). Quarum opus Antonii Żołędziowski sine auctoris nomine Romae latine et italice editum laudandum nobis sit, quamquam fere nihil novi ad vitam tum maxime canonizati professoris Cracoviensis scriptor recensuit. Idem de libro Ioesephi Putanovicz (1780) dicere possumus. 
Cunctam admodum materiam litterarum de vita cultu, canonizatione Ioannis de Kęty libellus Beniamini Bossue volumine VIII (octobris) Actorum Sanctorum a Bollandistis editorum (1866) contentus praebet. Auctor singula quaevis persecutus Vitam eximii viri Ioannis Cantii ab A. Opatovio compilatum, miracula aliaque maximi momenti documenta, quibus pristinas opiniones de Cantio cognosci possunt, affert.

Saeculo quidem XIX et $\mathrm{XX}$ divulgatae quoque sunt duae dissertatiunculae aeque compendiosae ac auctoritate penitus diversae. Alteram Vladislaus Wisłocki anno 1890 edidit usurpatis documentis Academiae Cracoviensis et praesertim manuscriptis Cantii tunc a se in Bibliotheca Jagellonica Cracoviae repertis, parum quidem correctam et satis futilibus commenticisque rationibus refertam elaboravit. Attamen auctores, qui postea ex ista dissertatione singula de vita Cantii hauriebant, neglectis fabulosis quibusdam rationibus fere omnes Vladislai Wisłocki excogitata de vita illius Sancti rata habuerant et scriptis suis inseruerunt.

Alteram hagiographicam enarrationem Marianus Rechowicz nuper maxime in I volumine Hagiographiae Polonae (1971) proposuit. Ille quidem auctor, quamvis cum nonnullis V. Wisłocki rationibus pene consentiat, attamen rem Cantianam cum accurata diligentia enucleavit. Quam igitur biographiam nec non historiam immortalis cultus s. Ioannis de Kęty basim ac fundamentum, quo eiusdem rei inquisitiones nostrae niti abinde debent habeamus.

De manuscriptis s. Joannis Cantii pauca dicemus, nam res et difficilis et minime adhuc dilucida explicatuque apta nobis videtur. Collectio Ioannis manuscriptorum XXVII volumina continet, quorum XVII in Bibliotheca Jagellonica, $\mathrm{X}$ vero in Bibliotheca Vaticana asservata sunt. Haec anno 1728 Roman ad Congregationem Rituum canonizationis causa Ioannis Cantii exportata non ita duobus ante annis (1972) reperta ibidem sunt; illa autem a V. Wisłocki etiam descripta iam dudum nobis nota sunt. Singulorum manuscriptorum, quae maxima ex parte autographa ipsius magistri de Kęty sunt, primum signaturas iuxta ordinem Catalogi indicavi et descripsi, annos deinde quibus unumquodque a Cantio conscriptum erat institui argumentisque heu non semper firmis roboravi, post demum opera certa et ignotorum auctorum a Ioanne Cantio exscripta enumeravi. Quaedam his ex scriptis ipsiusmet magistri de Kęty auctoris haberi possint, sed res sane incerta nobis videtur.

Dum s. Ioannis de Kęty assiduitatem illam laboriosam investigare nitimur, non solum copia tractatuum exscriptorum admirationem nostram excitat, sed quoque adnotationes plurimae marginales et glossae frequenter polonica lingua redditae variisque temporibus ab ipso asscriptae, ex quibus efficitur ut omnibus his operibus s. Ioannes Cantius toto animo studeret, quod dubium minime est. 